\title{
10. THE PETROLOGY OF MAGMATIC ROCKS, DSDP LEG 38
}

\author{
G.N. Kharin, the Atlantic Branch, P.P. Shirshov Institute of Oceanology, \\ USSR Academy of Sciences, Kaliningrad
}

\begin{abstract}
During Leg 38 basalt, dolerite, and gabbro-dolerite were recovered from nine sites in the Norwegian-Greenland Sea. The upper part of the acoustic basement of two sites (Site 345 on the eastern flank of the Mohns Ridge, and Site 350 on the southern part of the Jan-Mayen Ridge) consists of highly altered basaltic (tuff) breccia. In the upper part of basement at Site 336 (the northern slope of the Iceland-Faeroe Ridge), there is a red chemical weathering crust which grades downward into fresh basalt. Relics of basaltic eluvium were also found in the upper part of basement at Site 342 (the V $\phi$ ring Plateau). Flow basalt was recovered at only two sites (Site 337 on the eastern flank of the Norwegian Seamounts and Site 345 on the eastern flank of the Mohns Ridge). Hole 344 (on the Knipovich Ridge) recovered a subabyssal intrusive body of dolerite (diabase), gabbro-dolerite, and gabbro. Basalt of other sites $(336,338,342$, $343,348,350$ ) may be the sills or dikes; however, the presence of thick basalt flows is not improbable. The basalts have different degrees of alteration; the basalt at Site 343 has the most alteration and the basalt at Site 350 has the least alteration.

Based on chemical characteristics the basaltic rocks are divided into two main types: (1) low-alkaline tholeiite (Sites 336, 338, 348), and (2) alkaline and subalkaline basalt (Sites 337, 342, 343, 350). High-alumina subalkaline basalts are present at Site 350. Except for Sites 344 and 345, basalts of all others site have a high iron content. This is typical for the northern Atlantic volcanic province. A high titanium content is also notable. It should be noted that the Leg 38 basalts are: (1) closely related to the Paleogene-Neogene plateaubasalt of East Iceland and Faeroe Islands (Sites 337 342, 350); (2) are similar to the tholeiites of the Mid-Atlantic Ridge (Sites 336, 338,348 ), differing from them by low magnesium content and a high iron content; and (3) they are similar to transform fracture zone basalts (Sites 343, 344, 345). However, the basalts of any region have their own specific properties. This suggests heterogeneity of the earth's crustal structure and in the composition of the mantle.
\end{abstract}

\section{INTRODUCTION}

Magmatic rocks comprising acoustic basement of the Norway and Greenland seas were cored from nine sites during DSDP Leg 38 (Figure 1). On the northern slope of the Iceland-Faeroe Ridge, basalts, dolerite basalts, and amygdaloidal basalts were drilled (Site 336). On the eastern flank of the "extinct axis" Site 337 revealed glassy basalts. Porphyritic basalts and dolerite basalts with native copper were drilled at Sites 338 and 342 on the V $\phi$ ring Plateau. Spilitic basalts were cored at Site 343 in the Lofoten Basin. On the eastern flank of the Mohns Ridge, basaltic tuffs (breccia) and alkaline glassy basalts were drilled (Site 345 ). A subabyssal intrusive body of diabases and gabbro-diabases was recovered on the Knipovich Ridge (Site 344 ). On the Iceland Plateau, Site 348 contained tholeiitic basalts. Basaltic tuffs (breccia), basalts, and dolerite basalts were cored at Site 350 in the southern part of the JanMayen Ridge.

Magmatic rocks are exposed to secondary alterations. As a consequence, carbonates (calcite), smectites, and chlorites are abundant. Zeolites, hydrobiotites, tremolites, leucoxenes, and other minerals are rare. Marked pyritization (Site 344) and albitization (Sites 343 and 344) can be observed. There is also ore mineralization in the form of fine native copper (Site 342).

Petrochemically, one can distinguish two basalt types in spite of strong secondary alterations: basalts similar to oceanic tholeiites, and alkali and subalkali basalts typical of transform fracture zones and seamounts.

\section{ICELAND-FAEROE RIDGE}

Site 336 drilled on the northern slope of the IcelandFaeroe Ridge recovered in the 463 to 486 meter inter$\mathrm{val}$, a red clay which passed into basalts. Basalts were recovered to a total depth of 515 meters below the sea floor.

This red zone appears to be an old chemical weathering crust developed at the expense of volcanogenic rocks. The data of a petrographic study (Table 1), and the results of chemical analyses (Tables 2, 3 and Figure 2) confirm this. Relict textures typical of volcanic tuffs 


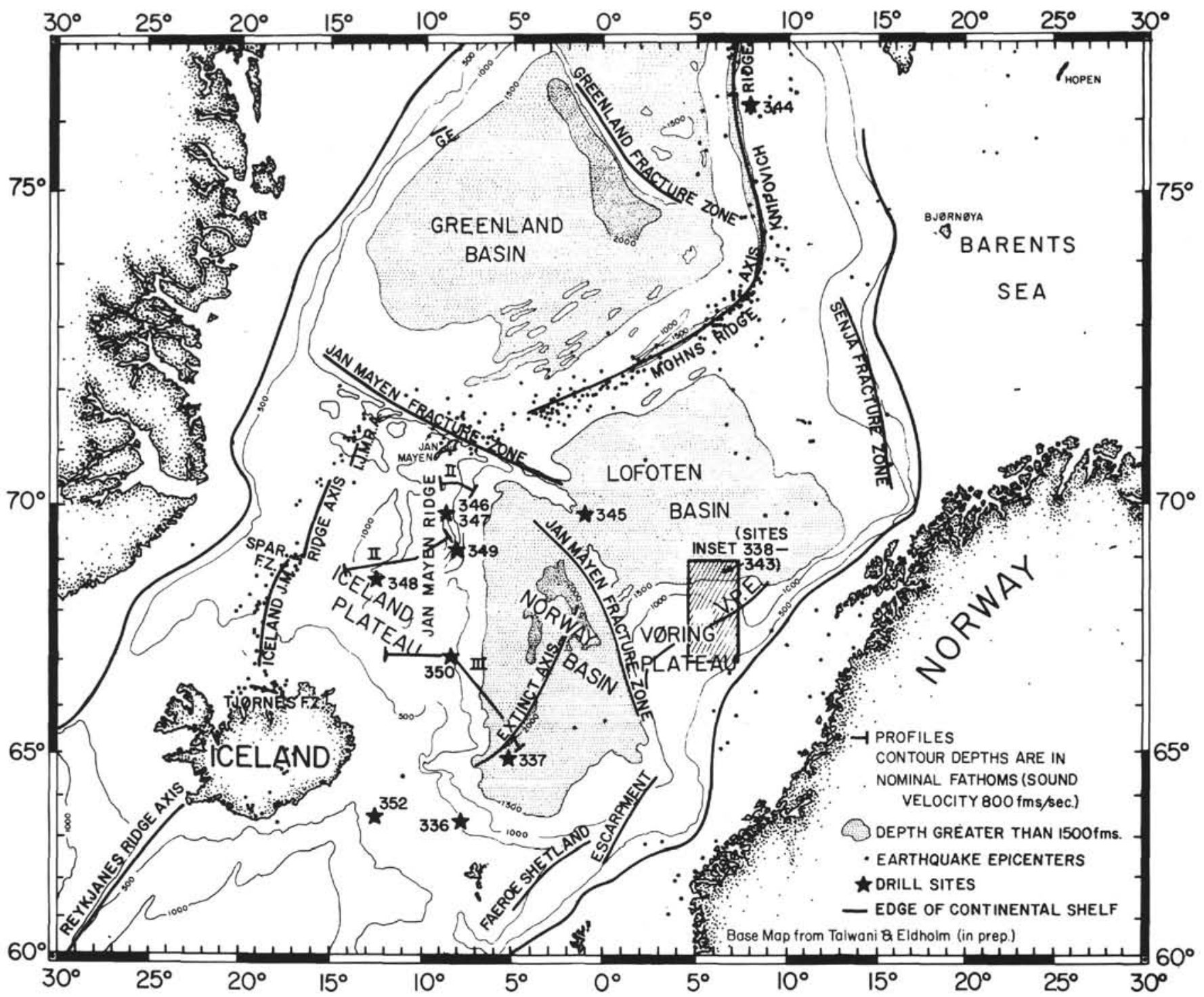

Figure 1. Index map, Leg 38 sites.

and basalts can be seen in the thin sections. Strongly weathered basalts (specimens of which easily crumble) are present in the lower part of the red sediments.

A recalculation of the chemical analysis data with allowance for the rock volume weight (Table 3) shows that the chemical element distribution in the red strata profile (Site 336) is affected by weathering, beginning from slightly weathered basalts (Sample 40, CC) and higher (to Sample 38-1, 142-144). The amounts of silica, ferrous iron, magnesium, calcium, sodium, potassium, phosphate, and sulphur gradually decrease with increasing depth, while the amounts of titanium, aluminium, and ferric iron gradually increase (Figure 2). A similar regularity in the distribution of these chemical elements was found in chemical weathering crusts of Tahiti (Lisitzina, 1973). The distribution of clay minerals is typical for a weathering crust profile. Montmorillonite is prevalent in the lower part, kaolinite appears above and prevails in the upper part.

A petrographic study shows that there are three main varieties of basalts: fine-grained polyphyric basalts, dolerite basalts, and amygdaloidal basalts (see Site Report Chapter 2, this volume for petrologic descriptions; see also Plate 1, Figures 1, 2).

The primary mineral composition of basalts is altered slightly (Table 1). Chlorites, smectites, and calcite prevail among secondary minerals. They are found in veins and amygdules, fill vesicles, and replace pyroxene and plagioclase phenocrysts. Hydrobiotite with a typical biotite pleochroism is rarely found. Hydrobiotite appears to develop at the expense of olivine and pyroxene. Often its content will reach $3 \%$ $5 \%$.

The chemical analysis represents seven samples (Table 2, Site 336, Cores 40-44) chosen from cores with little secondary alterations. The $\mathrm{K}_{2} \mathrm{O}-\mathrm{H}_{2} \mathrm{O}$ diagram (Figure 3 ) shows that the basalt chemical composition is slightly affected by weathering and metasomatosis. From the $\mathrm{CaO}-\mathrm{Al}_{2} \mathrm{O}_{3}$ diagram (Figure 4) it can be seen that the basalt points of Site 336 form two lines. One line defines the directly proportional dependence of these components. This may be related to crystalliza- 
TABLE 1

Modal Mineral Composition (\%) of Magmatic Rocks from DSDP Leg 38

\begin{tabular}{|c|c|c|c|c|c|c|c|}
\hline $\begin{array}{c}\text { Sample } \\
\text { (Interval in } \mathrm{cm} \text { ) }\end{array}$ & Olivine & Pyroxene & $\begin{array}{l}\text { Plagio- } \\
\text { clase }\end{array}$ & $\begin{array}{l}\text { Iron } \\
\text { Ore }\end{array}$ & $\begin{array}{c}\text { Altered } \\
\text { Glass and } \\
\text { Mesostasis }\end{array}$ & Accessories & $\begin{array}{c}\text { Iron } \\
\text { Sulphide } \\
\text { (pyrite) }\end{array}$ \\
\hline $336-41-1,10-13$ & $\operatorname{tr}$ & 50 & 35 & 10 & 5 & $\operatorname{tr}$ & - \\
\hline $336-41-1,147-150$ & $\operatorname{tr}$ & 40 & 50 & 5 & 5 & - & - \\
\hline $336-41-1,85-88$ & $\operatorname{tr}$ & 35 & 45 & 10 & 10 & $\operatorname{tr}$ & - \\
\hline $336-42-1,144-147$ & - & 45 & 45 & 5 & 5 & - & - \\
\hline $336-43-1,123-126$ & $\operatorname{tr}$ & 43 & 35 & 12 & 10 & $\operatorname{tr}$ & - \\
\hline $336-44-1,95-97$ & $\operatorname{tr}$ & 45 & 40 & 8 & 7 & - & - \\
\hline $336-44-2,71-74$ & 3 & 45 & 40 & 7 & 5 & - & - \\
\hline $337-13-1,80-83$ & 7 & 40 & 15 & 13 & 25 & $\operatorname{tr}$ & - \\
\hline $337-13-2,37-40$ & 5 & 40 & 23 & 12 & 20 & - & - \\
\hline $337-14-1,82-85$ & 3 & 40 & 27 & 10 & 20 & - & - \\
\hline $337-14-2,91-94$ & 6 & 40 & 20 & 10 & 24 & - & - \\
\hline $337-14-3,8-11$ & - & - & 55 & 15 & 30 & - & - \\
\hline $337-15-1,115-118$ & 5 & 35 & 30 & 10 & 20 & - & - \\
\hline $337-15-2,9-12$ & 12 & 30 & 25 & 13 & 20 & - & - \\
\hline $338-42-2,144-147$ & 20 & 30 & 35 & 10 & 5 & - & - \\
\hline $338-43-1,141-143$ & - & 45 & 45 & 7 & 3 & $\operatorname{tr}$ & - \\
\hline $338-43-2,43-46$ & - & 47 & 45 & 5 & 3 & $\operatorname{tr}$ & - \\
\hline $338-43-3,108-111$ & $\operatorname{tr}$ & 45 & 45 & 5 & 5 & $\mathrm{tr}$ & - \\
\hline $338-43-4,100-103$ & 1 & 48 & 43 & 7 & 1 & $\operatorname{tr}$ & - \\
\hline $338-44-2,65-68$ & $\operatorname{tr}$ & 42 & 48 & 6 & 4 & $\operatorname{tr}$ & - \\
\hline $338-44-3,48-51$ & 20 & 30 & 30 & 10 & 10 & $\operatorname{tr}$ & - \\
\hline $338-45-1,92-95$ & 3 & 45 & 43 & 6 & 3 & $\operatorname{tr}$ & - \\
\hline $338-45-2,128-131$ & 1 & 43 & 50 & 5 & 1 & $\operatorname{tr}$ & - \\
\hline $342-7-1,120-123$ & 1 & 40 & 45 & 10 & 4 & $\operatorname{tr}$ & - \\
\hline $342-7-2,4-7$ & 2 & 43 & 43 & 8 & 7 & $\operatorname{tr}$ & - \\
\hline $342-7-2,40-43$ & $\operatorname{tr}$ & 35 & 40 & 15 & 10 & $\operatorname{tr}$ & - \\
\hline $342-7-3,54-58$ & 2 & 40 & 48 & 7 & 3 & $\operatorname{tr}$ & - \\
\hline $342-7-5,68-71$ & 2 & 35 & 53 & 6 & 4 & $\operatorname{tr}$ & $\operatorname{tr}$ \\
\hline $342-8-3,140-143$ & $\operatorname{tr}$ & 35 & 40 & 15 & 10 & tr & $\operatorname{tr}$ \\
\hline $342-8-4,127-130$ & - & 42 & 43 & 10 & 5 & $\operatorname{tr}$ & - \\
\hline $343-12-2,134-136$ & 2 & 28 & 40 & 12 & 15 & tr & 1 \\
\hline $343-13-1,42-45$ & 1 & 26 & 42 & 11 & 15 & $\operatorname{tr}$ & 1 \\
\hline $343-13-2,5-8$ & $\operatorname{tr}$ & 7 & 50 & 13 & 29 & tr & 1 \\
\hline $343-16-3,97-100$ & 1 & 30 & 36 & 12 & 20 & - & 1 \\
\hline $343-16-3,144-147$ & - & 9 & 50 & 20 & 20 & - & 1 \\
\hline $344-34-1,114-117$ & - & 44 & 50 & 5 & $\operatorname{tr}$ & $\operatorname{tr}$ & 1 \\
\hline $344-34-2,127-130$ & - & 48 & 47 & 4 & $\mathrm{tr}$ & $\operatorname{tr}$ & 1 \\
\hline $344-34-4,17-20$ & - & 30 & 63 & 3 & $\operatorname{tr}$ & $\operatorname{tr}$ & 4 \\
\hline $344-35-3,12-15$ & - & 33 & 60 & 4 & $\operatorname{tr}$ & 1 & 3 \\
\hline $344-36-1,142-144$ & - & 50 & 46 & 3 & $\operatorname{tr}$ & $\operatorname{tr}$ & 1 \\
\hline $344-36-2,75-77$ & $\operatorname{tr}$ & 45 & 51 & 3 & $\operatorname{tr}$ & $\operatorname{tr}$ & 1 \\
\hline $344-35-4,36-39$ & 3 & 40 & 50 & 5 & 1 & $\operatorname{tr}$ & 1 \\
\hline $344-36-3,72-74$ & $\operatorname{tr}$ & 36 & 55 & 8 & $\operatorname{tr}$ & $\operatorname{tr}$ & 1 \\
\hline $344-36-4,72-74$ & $\operatorname{tr}$ & 47 & 47 & 5 & $\operatorname{tr}$ & $\operatorname{tr}$ & 1 \\
\hline $344-37-1,140-142$ & 4 & 44 & 46 & 4 & 1 & tr & 1 \\
\hline $344-37-3,135-137$ & $\operatorname{tr}$ & 44 & 50 & 5 & $\operatorname{tr}$ & $\operatorname{tr}$ & 1 \\
\hline $345-32-3,60-63$ & 5 & - & 25 & 10 & 60 & - & - \\
\hline $345-34-2,128-131$ & 5 & - & 50 & 15 & 30 & - & - \\
\hline $345-35-1,145-148$ & $\operatorname{tr}$ & 30 & 30 & 10 & 20 & - & - \\
\hline $345-35-2,43-46$ & 3 & 10 & 45 & 12 & 30 & - & - \\
\hline $345-35-3,27-30$ & 2 & $\operatorname{tr}$ & 53 & 10 & 35 & - & - \\
\hline $345-35$, CC & 5 & $\operatorname{tr}$ & 55 & 15 & 25 & - & - \\
\hline $345-36-1,98-100$ & $\mathrm{tr}$ & 10 & 55 & 15 & 20 & - & - \\
\hline $348-32-4,36-38$ & 2 & 30 & 30 & 8 & 30 & - & - \\
\hline $348-33-1,102-105$ & 3 & 48 & 37 & 7 & 5 & - & - \\
\hline $348-33-2,143-146$ & 3 & 45 & 40 & 8 & 7 & - & - \\
\hline $348-34-1,132-135$ & 5 & 50 & 42 & 8 & 5 & - & - \\
\hline $348-34-2,146-149$ & $\operatorname{tr}$ & 35 & 60 & 5 & $\operatorname{tr}$ & - & - \\
\hline $350-16-1,112-115$ & 3 & 40 & 42 & 10 & 5 & - & - \\
\hline $350-16-3,13-16$ & $\operatorname{tr}$ & 40 & 42 & 8 & 10 & - & - \\
\hline $350-16-3,114-117$ & $\mathrm{tr}$ & 40 & 40 & 10 & 10 & - & - \\
\hline $350-16-3,147-149$ & 3 & 35 & 45 & 10 & 7 & - & - \\
\hline
\end{tabular}

tion differentiation and plagioclase increasing in basalt; the second line perpendicular to the abscissa shows $\mathrm{CaO}$ increasing with $\mathrm{Al}_{2} \mathrm{O}_{3}$ remaining constant. This is related to basalt calcitization.
Other diagrams (Figures 5-8) demonstrate the rather uniform chemical composition of basalt. Normative quartz and diopside-hypersthene variation are typical for the basalt at Site 336 (Figure 9). 
TABLE 2

Chemical Analyses (wt \%) and CIPW Norms of Magmatic Rocks, Volcanic Tuff Breccia and Weathering Products, DSDP, Leg 38

\begin{tabular}{|c|c|c|c|c|c|c|c|c|c|c|c|c|c|c|c|c|}
\hline & & & & & & & & Site 336 & & & & & & & & \\
\hline & $\begin{array}{c}38-1, \\
142-144 \\
\mathrm{~cm}\end{array}$ & $38, \mathrm{CC}$ & $\begin{array}{c}39-1, \\
150 \mathrm{~cm} \\
\end{array}$ & $\begin{array}{c}39-2 \\
35 \mathrm{~cm}\end{array}$ & $\begin{array}{c}39-2, \\
140 \mathrm{~cm} \\
\end{array}$ & $\begin{array}{c}39-3 \\
130 \mathrm{~cm} \\
\end{array}$ & $\begin{array}{r}39-4 \\
0-1 \mathrm{~cm} \\
\end{array}$ & $\begin{array}{c}39-5 \\
130 \mathrm{~cm}\end{array}$ & $39, \mathrm{CC}$ & $40, \mathrm{CC}$ & $\begin{array}{c}41-1, \\
10 \mathrm{~cm} \\
\end{array}$ & $\begin{array}{c}42-1, \\
145 \mathrm{~cm} \\
\end{array}$ & $\begin{array}{c}42-2 \\
82-84 \mathrm{~cm} \\
\end{array}$ & $\begin{array}{c}43-1 \\
123-126 \\
\mathrm{~cm}\end{array}$ & $\begin{array}{c}44-1, \\
94-97 \mathrm{~cm}\end{array}$ & $\begin{array}{c}44-2, \\
105-108 \\
\mathrm{~cm} \\
\end{array}$ \\
\hline & 1 & 2 & 3 & 4 & 5 & 6 & 7 & 8 & 9 & 10 & 11 & 12 & 13 & 14 & 15 & 16 \\
\hline $\mathrm{SiO}_{2}$ & 30.56 & 30.73 & 45.81 & 45.21 & 42.20 & 47.62 & 50.90 & 51.77 & 54.16 & 48.91 & 49.53 & 49.34 & 50.39 & 48.66 & 49.58 & 50.22 \\
\hline $\mathrm{TiO}_{2}$ & 4.56 & 4.23 & 4.12 & 4.12 & 4.62 & 2.28 & 2.43 & 2.31 & 2.03 & 1.97 & 1.73 & 1.85 & 1.85 & 1.35 & 1.87 & 1.81 \\
\hline $\mathrm{Al}_{2} \mathrm{O}_{3}$ & 25.56 & 25.89 & 21.03 & 20.93 & 21.55 & 19.39 & 19.96 & 21.21 & 17.40 & 16.80 & 14.51 & 14.88 & 15.92 & 15.96 & 16.09 & 16.15 \\
\hline $\mathrm{Fe}_{2} \mathrm{O}_{3}$ & 25.80 & 25.46 & 16.02 & 16.43 & 17.79 & 17.62 & 12.65 & 8.95 & 11.12 & 7.29 & 5.82 & 7.08 & 3.99 & 4.11 & 6.16 & 7.92 \\
\hline $\mathrm{FeO}$ & 0.59 & 0.44 & 0.30 & 0.22 & 0.22 & 0.30 & 0.30 & 1.18 & 0.96 & 5.90 & 7.03 & 5.31 & 6.94 & 5.61 & 5.51 & 4.13 \\
\hline $\mathrm{MnO}$ & 0.13 & 0.13 & 0.07 & 0.08 & 0.10 & 0.08 & 0.06 & 0.11 & 0.10 & 0.14 & 0.26 & 0.18 & 0.17 & 0.26 & 0.25 & 0.24 \\
\hline $\mathrm{MgO}$ & 0.56 & 0.59 & 0.96 & 1.29 & 1.49 & 2.45 & 2.67 & 1.48 & 2.97 & 5.03 & 6.90 & 6.54 & 6.57 & 8.17 & 6.34 & 5.41 \\
\hline $\mathrm{CaO}$ & 0.42 & 0.42 & 1.36 & 1.23 & 1.52 & 1.39 & 1.25 & 5.92 & 2.46 & 7.29 & 10.47 & 10.76 & 9.56 & 11.94 & 9.69 & 8.54 \\
\hline $\mathrm{Na}_{2} \mathrm{O}$ & 0.80 & 0.79 & 1.64 & 1.78 & 1.30 & 1.50 & 1.69 & 3.16 & 2.28 & 2.86 & 2.38 & 2.48 & 2.86 & 2.18 & 2.70 & 2.76 \\
\hline $\mathrm{K}_{2} \mathrm{O}$ & 0.08 & 0.07 & 0.24 & 0.24 & 0.21 & 0.20 & 0.20 & 0.28 & 0.38 & 0.22 & 0.18 & 0.20 & 0.16 & 0.22 & 0.25 & 0.38 \\
\hline $\mathrm{P}_{2} \mathrm{O}_{5}$ & 0.15 & 0.16 & 0.04 & 0.07 & 0.13 & 0.07 & 0.12 & 0.28 & 0.08 & 0.15 & 0.15 & 0.15 & 0.14 & 0.12 & 0.11 & 0.11 \\
\hline LOI & 10.77 & 10.86 & 8.38 & 8.89 & 9.35 & 6.47 & 7.60 & 3.59 & 6.43 & 2.39 & 0.94 & 0.88 & 1.12 & 1.26 & 1.20 & 1.90 \\
\hline Total & 99.98 & 99.77 & 99.97 & 94.49 & 100.48 & 99.37 & 99.83 & 100.24 & 100.37 & 98.95 & 99.90 & 99.65 & 99.67 & 99.84 & 99.75 & 99.57 \\
\hline $\mathrm{S}$ & 0.01 & 0.07 & 0.02 & 0.01 & 0.01 & tr & 0.02 & 0.01 & 0.07 & 0.22 & 0.01 & 0.06 & 0.02 & $\operatorname{tr}$ & $\operatorname{tr}$ & 0.01 \\
\hline $\mathrm{CO}_{2}$ & 0.18 & 0.05 & 0.23 & 0.23 & 0.28 & 0.27 & 0.14 & 0.27 & 0.14 & 0.50 & n.d. & 0.14 & 0.27 & 0.14 & 0.00 & 0.27 \\
\hline CIPW Norm. & & & & & & & & & & 4.10 & 1.84 & 1.90 & 2.84 & 0.00 & 2.15 & 4.47 \\
\hline Q & & & & & & & & & & 1.34 & 1.08 & 1.20 & 0.96 & 1.32 & 1.50 & 2.31 \\
\hline or & & & & & & & & & & 25.20 & 20.43 & 21.36 & 24.61 & 10.76 & 23.27 & 24.05 \\
\hline$a b$ & & & & & & & & & & 33.59 & 28.79 & 29.39 & 30.64 & 33.67 & 31.63 & 31.47 \\
\hline an & & & & & & & & & & 0.00 & 0.00 & 0.00 & 0.00 & 0.00 & 0.00 & 0.00 \\
\hline ne & & & & & & & & & & 1.66 & 9.98 & 10.41 & 7.34 & 11.09 & 7.24 & 5.08 \\
\hline wo ) & & & & & & & & & & 0.85 & 5.60 & 6.04 & 4.57 & 7.31 & 4.31 & 2.80 \\
\hline & & & & & & & & & & 0.77 & 3.97 & 3.89 & 2.33 & 2.99 & 2.56 & 2.38 \\
\hline fs $J$ & & & & & & & & & & 12.20 & 11.83 & 10.54 & 12.07 & 11.36 & 11.78 & 11.07 \\
\hline en $\}_{\text {hy }}$ & & & & & & & & & & 11.12 & 8.39 & 6.77 & 6.16 & 4.66 & 6.99 & 8.23 \\
\hline fs $\int$ & & & & & & & & & & 0.00 & 0.00 & 0.00 & 0.00 & 1.42 & 0.00 & 0.00 \\
\hline fo 7 ol & & & & & & & & & & 0.00 & 0.00 & 0.00 & 0.00 & 0.64 & 0.00 & 0.00 \\
\hline fa $\int^{\text {ol }}$ & & & & & & & & & & 5.16 & 4.73 & 4.92 & 4.91 & 4.17 & 4.95 & 4.89 \\
\hline $\begin{array}{l}\mathrm{mt} \\
\text { il }\end{array}$ & & & & & & & & & & 3.90 & 3.33 & 3.58 & 3.57 & 2.61 & 3.62 & 3.54 \\
\hline
\end{tabular}


TABLE 2 - Continued

\begin{tabular}{|c|c|c|c|c|c|c|c|c|c|c|c|c|c|c|c|}
\hline & \multicolumn{5}{|c|}{ Site 337} & \multicolumn{6}{|c|}{ Site 338} & \multicolumn{4}{|c|}{ Site 342} \\
\hline & $\begin{array}{c}13-1 \\
80-83 \mathrm{~cm}\end{array}$ & $\begin{array}{c}13-2, \\
37-40 \mathrm{~cm}\end{array}$ & $\begin{array}{c}14-2, \\
91-94 \mathrm{~cm} \\
\end{array}$ & $\begin{array}{c}14-3, \\
128-131 \\
\mathrm{~cm}\end{array}$ & $\begin{array}{c}15-1, \\
127-130 \\
\mathrm{~cm}\end{array}$ & $\begin{array}{c}42-2 \\
144-147 \\
\mathrm{~cm}\end{array}$ & $\begin{array}{c}43-1 \\
141-143 \\
\mathrm{~cm}\end{array}$ & $\begin{array}{c}43-3, \\
43-45 \mathrm{~cm}\end{array}$ & $\begin{array}{c}44-2, \\
65-68 \mathrm{~cm} \\
\end{array}$ & $\begin{array}{c}44-3 \\
48-51 \mathrm{~cm} \\
\end{array}$ & $\begin{array}{c}45-2, \\
47-50 \mathrm{~cm} \\
\end{array}$ & $\begin{array}{c}7-2 \\
40-43 \mathrm{~cm} \\
\end{array}$ & $\begin{array}{c}7-3, \\
55-58 \mathrm{~cm} \\
\end{array}$ & $\begin{array}{c}7-4, \\
30-33 \mathrm{~cm}\end{array}$ & $\begin{array}{c}7-5, \\
4-7 \mathrm{~cm} \\
\end{array}$ \\
\hline & 17 & 18 & 19 & 20 & 21 & 22 & 23 & 24 & 25 & 26 & 27 & 28 & 29 & 30 & 31 \\
\hline $\mathrm{SiO}_{2}$ & 48.95 & 47.54 & 49.00 & 42.12 & 47.43 & 45.69 & 47.81 & 47.89 & 49.62 & 47.56 & 47.72 & 48.81 & 49.94 & 49.17 & 48.81 \\
\hline $\mathrm{TiO}_{2}$ & 1.43 & 1.41 & 1.41 & 1.19 & 1.38 & 1.34 & 1.47 & 1.29 & 1.29 & 1.67 & 1.51 & 2.94 & 2.98 & 2.76 & 2.76 \\
\hline $\mathrm{Al}_{2} \mathrm{O}_{3}$ & 15.03 & 14.85 & 15.79 & 12.99 & 14.70 & 17.38 & 15.21 & 17.23 & 16.39 & 17.31 & 16.14 & 15.03 & 14.88 & 14.67 & 14.49 \\
\hline $\mathrm{Fe}_{2} \mathrm{O}_{3}$ & 5.50 & 4.95 & 4.64 & 7.10 & 5.75 & 6.05 & 6.70 & 3.83 & 5.46 & 6.60 & 6.03 & 4.59 & 4.04 & 4.43 & 5.16 \\
\hline $\mathrm{FeO}$ & 5.76 & 5.90 & 5.90 & 3.99 & 3.38 & 4.13 & 5.76 & 5.90 & 6.05 & 4.43 & 5.98 & 7.53 & 8.12 & 8.41 & 8.56 \\
\hline $\mathrm{MnO}$ & 0.21 & 0.19 & 0.18 & 0.15 & n.d. & 0.23 & 0.15 & 0.15 & 0.21 & 0.20 & n.d. & 0.32 & 0.18 & 0.20 & 0.20 \\
\hline $\mathrm{MgO}$ & 7.65 & 7.52 & 7.24 & 7.18 & 7.03 & 8.72 & 9.99 & 8.15 & 9.92 & 8.27 & 7.23 & 5.83 & 5.83 & 5.63 & 5.83 \\
\hline $\mathrm{CaO}$ & 11.84 & 11.87 & 11.33 & 15.42 & 12.85 & 10.41 & 7.81 & 11.02 & 8.33 & 8.04 & 11.17 & 11.01 & 10.07 & 10.30 & 10.12 \\
\hline $\mathrm{Na}_{2} \mathrm{O}$ & 2.18 & 2.88 & 2.48 & 2.20 & 2.18 & 2.66 & 2.66 & 2.28 & 2.48 & 2.96 & 2.18 & 2.86 & 2.86 & 2.86 & 2.86 \\
\hline $\mathrm{K}_{2} \mathrm{O}$ & 0.36 & 0.28 & 0.29 & 0.63 & 0.47 & 0.37 & 0.42 & 0.14 & 0.13 & 0.42 & 0.17 & 0.45 & 0.57 & 0.42 & 0.44 \\
\hline $\mathrm{P}_{2} \mathrm{O}_{5}$ & 0.11 & 0.10 & 0.14 & 0.20 & n.d. & 0.10 & 0.09 & 0.11 & 0.09 & 0.15 & n.d. & 0.20 & 0.28 & 0.25 & 0.25 \\
\hline LOI & 0.97 & 1.52 & 0.58 & 5.84 & 2.37 & 2.20 & 1.76 & 1.44 & 2.26 & 2.16 & 1.41 & 0.10 & 0.23 & 0.97 & 0.06 \\
\hline Total & 99.99 & 99.01 & 98.98 & 99.01 & 97.49 & 99.28 & 99.83 & 99.43 & 99.53 & 99.77 & 99.54 & 99.67 & 99.98 & 100.07 & 99.60 \\
\hline S & $\mathrm{tr}$ & 0.02 & 0.02 & 0.02 & n.d. & $\operatorname{tr}$ & $\operatorname{tr}$ & $\operatorname{tr}$ & $\operatorname{tr}$ & $\mathrm{tr}$ & n.d. & $\operatorname{tr}$ & 0.01 & 0.01 & $\operatorname{tr}$ \\
\hline $\begin{array}{l}\mathrm{CO}_{2} \\
\text { CIPW Norm. }\end{array}$ & 0.36 & 0.77 & 0.41 & 5.42 & 1.76 & 1.72 & 0.23 & 0.25 & 0.54 & 0.36 & 0.50 & 0.07 & 0.23 & 0.14 & 0.05 \\
\hline Q & 0.00 & 0.00 & 0.00 & 0.00 & 0.00 & 0.00 & 0.00 & 0.00 & 0.00 & 0.00 & 0.00 & 1.37 & 2.84 & 2.25 & 1.21 \\
\hline or & 2.16 & 1.70 & 1.75 & 4.02 & 2.86 & 2.26 & 2.54 & 0.85 & 0.79 & 2.56 & 1.03 & 2.68 & 3.39 & 2.51 & 2.62 \\
\hline$a b$ & 18.70 & 24.82 & 21.39 & 0.60 & 19.00 & 22.93 & 23.06 & 19.73 & 21.65 & 25.79 & 18.86 & 24.36 & 24.33 & 24.49 & 24.40 \\
\hline an & 30.57 & 27.54 & 31.70 & 25.62 & 29.81 & 35.58 & 29.02 & 37.19 & 34.26 & 33.68 & 34.50 & 27.02 & 26.22 & 26.26 & 25.60 \\
\hline ne & 0.00 & 0.14 & 0.00 & 10.57 & 0.00 & 0.20 & 0.00 & 0.00 & 0.00 & 0.00 & 0.00 & 0.00 & 0.00 & 0.00 & 0.00 \\
\hline wo & 12.09 & 13.80 & 10.69 & 23.82 & 14.97 & 7.45 & 4.46 & 7.82 & 3.50 & 3.08 & 9.25 & 11.67 & 10.02 & 10.62 & 10.44 \\
\hline en di & 7.37 & 8.50 & 6.62 & 14.04 & 8.91 & 4.92 & 2.01 & 5.13 & 2.23 & 2.01 & 5.45 & 7.63 & 6.34 & 6.39 & 6.02 \\
\hline fs & 4.05 & 4.50 & 3.44 & 8.61 & 5.30 & 2.01 & 1.38 & 2.14 & 1.04 & 0.87 & 3.35 & 3.24 & 3.05 & 3.67 & 3.95 \\
\hline en & 10.80 & 0.00 & 10.68 & 0.00 & 3.70 & 0.00 & 12.20 & 11.55 & 12.70 & 10.61 & 11.37 & 6.99 & 8.26 & 7.80 & 8.62 \\
\hline fs $\}^{\text {ny }}$ & 5.93 & 0.00 & 5.53 & 0.00 & 2.20 & 0.00 & 5.99 & 4.82 & 5.95 & 4.58 & 6.09 & 2.97 & 3.97 & 4.48 & 5.65 \\
\hline fo & 0.80 & 7.55 & 0.76 & 3.70 & 3.81 & 12.30 & 7.35 & 2.86 & 7.41 & 6.02 & 1.11 & 0.00 & 0.00 & 0.00 & 0.00 \\
\hline $\mathrm{fa} \int^{01}$ & 0.48 & 4.41 & 0.43 & 2.50 & 2.50 & 5.53 & 3.97 & 1.32 & 3.83 & 2.86 & 0.75 & 0.00 & 0.00 & 0.00 & 0.00 \\
\hline $\mathrm{mt}$ & 4.28 & 4.29 & 4.27 & 4.05 & 4.25 & 4.19 & 4.37 & 4.09 & 4.11 & 4.68 & 4.42 & 6.47 & 5.89 & 6.23 & 6.22 \\
\hline il & 2.75 & 2.76 & 2.73 & 2.44 & 2.70 & 2.63 & 2.86 & 2.51 & 2.53 & 3.27 & 2.93 & 5.62 & 5.69 & 5.30 & 5.28 \\
\hline
\end{tabular}


TABLE 2 - Continued

\begin{tabular}{|c|c|c|c|c|c|c|c|c|c|c|c|c|c|c|c|}
\hline & \multicolumn{2}{|l|}{ Site 342} & \multicolumn{6}{|c|}{ Site 343} & \multicolumn{7}{|c|}{ Site 344} \\
\hline & $\begin{array}{c}8-2 \\
20-23 \mathrm{~cm}\end{array}$ & $\begin{array}{c}8-3 \\
137-140 \\
\mathrm{~cm}\end{array}$ & $\begin{array}{c}12-2 \\
140-143 \\
\mathrm{~cm}\end{array}$ & $\begin{array}{c}13-1, \\
45-48 \mathrm{~cm}\end{array}$ & $\begin{array}{r}13-2 \\
5-8 \mathrm{~cm}\end{array}$ & $\begin{array}{c}13-2 \\
100-103 \\
\mathrm{~cm}\end{array}$ & $\begin{array}{c}14-1, \\
145-148 \\
\mathrm{~cm}\end{array}$ & $\begin{array}{c}16-3 \\
144-147 \\
\mathrm{~cm}\end{array}$ & $\begin{array}{c}34-1, \\
114-117 \\
\mathrm{~cm}\end{array}$ & $\begin{array}{c}34-3 \\
22-25 \mathrm{~cm}\end{array}$ & $\begin{array}{c}35-1, \\
67-90 \mathrm{~cm}\end{array}$ & $\begin{array}{c}35-2 \\
75-78 \mathrm{~cm}\end{array}$ & $\begin{array}{c}35-4, \\
36-69 \mathrm{~cm}\end{array}$ & $\begin{array}{c}36-2, \\
15-17 \mathrm{~cm}\end{array}$ & $\begin{array}{c}36-5, \\
34-36 \mathrm{~cm}\end{array}$ \\
\hline & 32 & 33 & 34 & 35 & 36 & 37 & 38 & 39 & 40 & 41 & 42 & 43 & 44 & 45 & 46 \\
\hline $\mathrm{SiO}_{2}$ & 49.30 & 49.90 & 45.77 & 44.40 & 45.05 & 45.73 & 47.78 & 46.41 & 49.06 & 45.48 & 45.45 & 49.34 & 50.70 & 50.58 & 50.56 \\
\hline $\mathrm{TiO}_{2}$ & 2.94 & 2.81 & 3.28 & 3.19 & 3.22 & 3.12 & 3.01 & 2.37 & 1.50 & 1.36 & 1.45 & 1.32 & 1.53 & 1.78 & 1.60 \\
\hline $\mathrm{Al}_{2} \mathrm{O}_{3}$ & 14.33 & 14.52 & 14.70 & 14.00 & 14.92 & 13.41 & 15.69 & 13.97 & 16.87 & 17.65 & 16.68 & 16.27 & 16.61 & 16.08 & 16.26 \\
\hline $\mathrm{Fe}_{2} \mathrm{O}_{3}$ & 5.84 & 4.92 & 11.43 & 10.80 & 10.07 & 9.30 & 9.35 & 8.82 & 2.88 & 4.11 & 3.93 & 3.06 & 3.62 & 4.47 & 3.65 \\
\hline $\mathrm{FeO}$ & 7.38 & 8.41 & 6.64 & 7.42 & 7.84 & 8.48 & 6.34 & 6.64 & 5.53 & 4.75 & 4.15 & 4.42 & 4.88 & 5.72 & 5.07 \\
\hline $\mathrm{MnO}$ & 0.19 & n.d. & 0.51 & 0.59 & 0.53 & 0.65 & n.d. & 0.46 & 0.18 & 0.21 & 0.17 & 0.19 & 0.20 & 0.21 & 0.18 \\
\hline $\mathrm{MgO}$ & 5.73 & 5.72 & 6.53 & 7.03 & 6.92 & 7.52 & 5.62 & 9.28 & 8.85 & 6.49 & 7.48 & 8.21 & 7.80 & 7.24 & 7.50 \\
\hline $\mathrm{CaO}$ & 9.79 & 10.33 & 4.32 & 4.74 & 4.30 & 3.43 & 3.77 & 5.73 & 9.76 & 10.87 & 9.99 & 9.03 & 10.00 & 9.59 & 10.12 \\
\hline $\mathrm{Na}_{2} \mathrm{O}$ & 2.76 & 2.52 & 3.80 & 3.62 & 3.54 & 3.42 & 3.14 & 3.04 & 2.86 & 3.04 & 3.16 & 3.24 & 3.16 & 3.34 & 3.24 \\
\hline $\mathrm{K}_{2} \mathrm{O}$ & 0.68 & 0.34 & 0.44 & 0.60 & 0.44 & 0.35 & 2.96 & 0.19 & 0.40 & 0.64 & 0.90 & 0.64 & 0.46 & 0.40 & 0.55 \\
\hline $\mathrm{P}_{2} \mathrm{O}_{5}$ & 0.27 & n.d. & 0.33 & 0.33 & 0.33 & 0.38 & n.d. & 0.25 & 0.21 & 0.18 & 0.17 & 0.20 & 0.20 & 0.19 & 0.22 \\
\hline LOI & 0.29 & 0.05 & 1.05 & 2.48 & 1.90 & 3.06 & 2.10 & 2.18 & 1.10 & 2.92 & 2.98 & 2.48 & 1.38 & 0.65 & 0.40 \\
\hline Total & 99.50 & 99.52 & 98.80 & 99.20 & 98.66 & 98.85 & 99.76 & 99.34 & 99.20 & 98.70 & 97.51 & 97.40 & 100.54 & 100.25 & 99.51 \\
\hline $\mathrm{S}$ & $\operatorname{tr}$ & n.d. & 0.21 & 0.21 & 0.18 & 0.15 & n.d. & 0.13 & 0.72 & 1.95 & 1.37 & 1.80 & 0.05 & 0.06 & 0.08 \\
\hline $\mathrm{CO}_{2}$ & 0.14 & 0.00 & 0.31 & 1.31 & 0.49 & 0.36 & 0.23 & 0.31 & 0.22 & 2.48 & 3.57 & 0.88 & 1.35 & 0.22 & 0.13 \\
\hline \multicolumn{16}{|l|}{ CIPW Norm. } \\
\hline Q & 2.79 & 4.45 & 0.00 & 0.100 & 0.00 & 0.00 & 0.00 & 0.00 & 0.00 & 0.00 & 0.00 & 0.00 & 0.00 & 0.00 & 0.00 \\
\hline or & 4.07 & 2.01 & 2.69 & 3.70 & 2.70 & 2.18 & 17.91 & 1.16 & 2.41 & 4.00 & 5.69 & 3.99 & 2.75 & 2.38 & 3.29 \\
\hline$a b$ & 23.64 & 21.38 & 33.23 & 31.98 & 31.11 & 30.48 & 27.20 & 26.68 & 24.72 & 22.56 & 23.29 & 28.95 & 27.04 & 28.46 & 27.74 \\
\hline an & 25.00 & 27.38 & 22.15 & 21.07 & 22.15 & 17.92 & 19.15 & 24.80 & 32.70 & 34.53 & 31.21 & 29.53 & 30.11 & 27.90 & 28.53 \\
\hline ne & 0.00 & 0.00 & 0.00 & 0.00 & 0.00 & 0.00 & 0.00 & 0.00 & 0.00 & 2.53 & 2.89 & 0.00 & 0.00 & 0.00 & 0.00 \\
\hline wo) & 10.09 & 10.03 & 0.00 & 1.45 & 0.00 & 0.00 & 0.00 & 1.66 & 7.00 & 9.42 & 9.12 & 7.42 & 8.37 & 8.36 & 9.65 \\
\hline \multirow{2}{*}{$\left.\begin{array}{l}\text { en } \\
\text { fs }\end{array}\right\}$ di } & 6.17 & 5.89 & 0.00 & 0.75 & 0.00 & 0.00 & 0.00 & 1.15 & 5.16 & 6.17 & 6.55 & 5.49 & 5.99 & 5.54 & 6.84 \\
\hline & 3.34 & 3.64 & 0.00 & 0.67 & 0.00 & 0.00 & 0.00 & 0.71 & 1.29 & 2.58 & 1.74 & 1.22 & 1.64 & 2.22 & 1.97 \\
\hline \multirow{2}{*}{$\left.\begin{array}{l}\text { en } \\
\text { fs }\end{array}\right\}$ hy } & 8.27 & 8.39 & 9.13 & 4.99 & 10.33 & 17.12 & 6.65 & 14.29 & 11.47 & 0.00 & 0.00 & 7.12 & 11.89 & 10.77 & 8.91 \\
\hline & 4.48 & 5.19 & 8.33 & 4.51 & 9.06 & 14.35 & 5.67 & 8.80 & 2.83 & 0.00 & 0.00 & 1.58 & 3.25 & 4.32 & 2.57 \\
\hline \multirow{4}{*}{$\begin{array}{l}\text { fo } \\
\text { fa } \\
\mathrm{mt} \\
\text { il }\end{array}$} & 0.00 & 0.00 & 5.38 & 8.79 & 5.30 & 1.83 & 5.38 & 5.98 & 4.47 & 7.67 & 9.38 & 6.30 & 1.24 & 1.30 & 2.21 \\
\hline & 0.00 & 0.00 & 5.42 & 8.74 & 5.13 & 1.69 & 5.06 & 4.05 & 1.26 & 3.54 & 2.75 & 1.54 & 0.37 & 0.57 & 0.70 \\
\hline & 6.50 & 6.27 & 7.11 & 7.02 & 7.04 & 6.96 & 6.66 & 5.76 & 4.27 & 4.27 & 4.43 & 4.20 & 4.42 & 4.78 & 4.53 \\
\hline & 5.65 & 5.35 & 6.44 & 6.33 & 6.35 & 6.24 & 5.85 & 4.67 & 2.91 & 2.73 & 2.95 & 2.65 & 2.94 & 3.40 & 3.07 \\
\hline
\end{tabular}


TABLE 2 - Continued

\begin{tabular}{|c|c|c|c|c|c|c|c|c|c|c|c|c|c|c|c|}
\hline & \multicolumn{2}{|c|}{ Site 344} & \multicolumn{6}{|c|}{ Site 345} & \multicolumn{2}{|c|}{ Site 348} & \multicolumn{5}{|c|}{ Site 350} \\
\hline & $\begin{array}{c}37-2 \\
70-72 \mathrm{~cm}\end{array}$ & $\begin{array}{c}37-3 \\
135-137 \\
\mathrm{~cm}\end{array}$ & $\begin{array}{c}32-3 \\
60-63 \mathrm{~cm}\end{array}$ & $\begin{array}{c}33-1, \\
126-129 \\
\mathrm{~cm}\end{array}$ & $\begin{array}{c}34-1 \\
48-56 \mathrm{~cm}\end{array}$ & $\begin{array}{c}34-2, \\
128-131 \\
\mathrm{~cm}\end{array}$ & $\begin{array}{c}35-1 \\
148-150 \\
\mathrm{~cm}\end{array}$ & $\begin{array}{c}35-2, \\
128-131 \\
\mathrm{~cm}\end{array}$ & $\begin{array}{c}33-2 \\
143-146 \\
\mathrm{~cm}\end{array}$ & $\begin{array}{c}34-2 \\
146-149 \\
\mathrm{~cm}\end{array}$ & $\begin{array}{c}14-2, \\
86-89 \mathrm{~cm}\end{array}$ & $\begin{array}{c}16-1, \\
74-77 \mathrm{~cm}\end{array}$ & $\begin{array}{c}16-1, \\
114-117 \\
\mathrm{~cm}\end{array}$ & $\begin{array}{c}16-2, \\
134-137 \\
\mathrm{~cm}\end{array}$ & $\begin{array}{c}16-3, \\
101-103 \\
\mathrm{~cm}\end{array}$ \\
\hline & 47 & 48 & 49 & 50 & 51 & 52 & 53 & 54 & 55 & 56 & 57 & 58 & 59 & 60 & 61 \\
\hline $\mathrm{SiO}_{2}$ & 49.51 & 49.81 & 41.26 & 47.23 & 45.48 & 47.01 & 46.88 & 46.95 & 47.61 & 49.48 & 35.56 & 43.34 & 47.54 & 48.77 & 48.63 \\
\hline $\mathrm{TiO}_{2}$ & 1.58 & 1.39 & 1.66 & 1.45 & 2.62 & 2.09 & 1.92 & 1.97 & 1.62 & 1.62 & 2.83 & 1.11 & 2.51 & 2.72 & 2.52 \\
\hline $\mathrm{Al}_{2} \mathrm{O}_{3}$ & 16.01 & 17.01 & 16.45 & 18.82 & 16.81 & 17.82 & 16.38 & 17.43 & 14.10 & 14.35 & 15.00 & 5.97 & 13.54 & 14.38 & 14.02 \\
\hline $\mathrm{Fe}_{2} \mathrm{O}_{3}$ & 3.74 & 2.98 & 5.40 & 8.68 & 7.35 & 5.00 & 5.46 & 5.89 & 5.80 & 4.74 & 3.65 & 4.91 & 4.35 & 4.24 & 3.88 \\
\hline $\mathrm{FeO}$ & 4.79 & 4.98 & 3.41 & 2.49 & 3.50 & 3.87 & 3.87 & 3.54 & 8.48 & 8.57 & 7.19 & 4.79 & 8.48 & 8.79 & 9.13 \\
\hline $\mathrm{MnO}$ & 0.17 & 0.18 & 0.76 & 0.17 & 0.22 & 0.26 & 0.32 & n.d. & 0.31 & 0.28 & 0.26 & 0.42 & 0.27 & 0.28 & 0.26 \\
\hline $\mathrm{MgO}$ & 7.81 & 7.31 & 7.23 & 11.15 & 10.65 & 9.38 & 10.54 & 10.80 & 6.90 & 6.84 & 4.25 & 5.87 & 5.57 & 6.04 & 6.25 \\
\hline $\mathrm{CaO}$ & 10.02 & 10.30 & 10.41 & 3.39 & 2.36 & 4.44 & 3.59 & 4.19 & 11.15 & 10.56 & 14.16 & 16.22 & 11.56 & 10.52 & 10.80 \\
\hline $\mathrm{Na}_{2} \mathrm{O}$ & 3.24 & 2.96 & 2.38 & 1.46 & 1.38 & 2.38 & 2.38 & 2.52 & 2.10 & 2.00 & 1.47 & 1.21 & 2.56 & 2.66 & 2.48 \\
\hline $\mathrm{K}_{2} \mathrm{O}$ & 0.49 & 0.66 & 1.68 & 2.00 & 1.18 & 1.91 & 2.38 & 1.70 & 0.07 & 0.08 & 0.88 & 0.57 & 0.32 & 0.37 & 0.27 \\
\hline $\mathrm{P}_{2} \mathrm{O}_{5}$ & 0.26 & 0.17 & 0.56 & 0.65 & 0.26 & 0.30 & 0.30 & n.d. & 0.13 & 0.12 & 0.23 & 0.22 & 0.30 & 0.29 & 0.32 \\
\hline LOI & 0.97 & 1.32 & 8.62 & 7.66 & 7.41 & 4.75 & 5.09 & 4.88 & 1.14 & 0.25 & 13.50 & 14.62 & 2.90 & 0.20 & 1.27 \\
\hline Total & 98.59 & 99.07 & 99.87 & 99.59 & 99.22 & 99.21 & 99.11 & 99.87 & 99.41 & 99.89 & 98.98 & 99.25 & 99.90 & 99.26 & 99.83 \\
\hline S & 0.97 & 0.05 & 0.03 & $\operatorname{tr}$ & 0.03 & 0.01 & 0.01 & n.d. & 0.10 & 0.09 & 0.11 & 0.32 & 0.04 & 0.02 & $\operatorname{tr}$ \\
\hline $\mathrm{CO}_{2}$ & 0.36 & 0.09 & 4.79 & 1.71 & 0.27 & 0.36 & 0.54 & 0.04 & 0.38 & 0.22 & 10.35 & 10.80 & 1.85 & 0.18 & 0.24 \\
\hline CIPW Norm. & & & & & & & & & & & & & & & \\
\hline Q & 0.00 & 0.00 & & & & 0.72 & 0.00 & 0.00 & 0.00 & 3.37 & & & 1.27 & 1.99 & 2.14 \\
\hline or & 2.98 & 4.00 & & & & 12.01 & 15.04 & 10.57 & 0.42 & 0.48 & & & 1.96 & 2.21 & 1.62 \\
\hline$a b$ & 28.18 & 25.67 & & & & 21.42 & 21.54 & 22.43 & 18.16 & 17.21 & & & 22.41 & 22.79 & 21.36 \\
\hline an & 28.46 & 31.95 & & & & 23.43 & 19.05 & 21.87 & 29.47 & 30.44 & & & 25.36 & 26.53 & 26.80 \\
\hline ne & 0.00 & 0.00 & & & & 0.00 & 0.00 & 0.00 & 0.00 & 0.00 & & & 0.00 & 0.00 & 0.00 \\
\hline wo) & 9.45 & 8.52 & & & & 0.00 & 0.00 & 0.00 & 11.29 & 9.53 & & & 14.17 & 10.99 & 11.58 \\
\hline en $\mathrm{di}$ & 6.80 & & & & & 0.00 & 0.00 & 0.00 & 5.81 & 5.10 & & & 8.11 & 6.58 & 6.75 \\
\hline fs & 1.80 & 6.09 & & & & 0.00 & 0.00 & 0.00 & 5.20 & 4.11 & & & 5.43 & 3.83 & 4.29 \\
\hline en & 7.74 & 10.06 & & & & 24.85 & 22.22 & 23.34 & 11.26 & 12.22 & & & 6.24 & 8.65 & 9.10 \\
\hline fs $\int$ ny & 2.04 & 2.78 & & & & 3.95 & 4.49 & 4.43 & 9.90 & 9.85 & & & 4.18 & 5.03 & 5.77 \\
\hline fo) & 3.83 & 1.76 & & & & 000 & 4.10 & 3.48 & 0.49 & 0.00 & & & 0.00 & 0.00 & 0.00 \\
\hline $\mathrm{fa} \mathrm{ol}$ & 1.11 & 0.54 & & & & 0.00 & 0.91 & 0.73 & 0.48 & 0.00 & & & 0.00 & 0.00 & 0.00 \\
\hline $\mathrm{mt}$ & 4.54 & 4.24 & & & & 5.41 & 5.16 & 5.19 & 4.58 & 4.57 & & & 5.95 & 6.17 & 5.73 \\
\hline il & 3.08 & 2.71 & & & & 4.22 & 3.90 & 3.04 & 3.14 & 3.13 & & & 4.93 & 5.23 & 4.87 \\
\hline
\end{tabular}




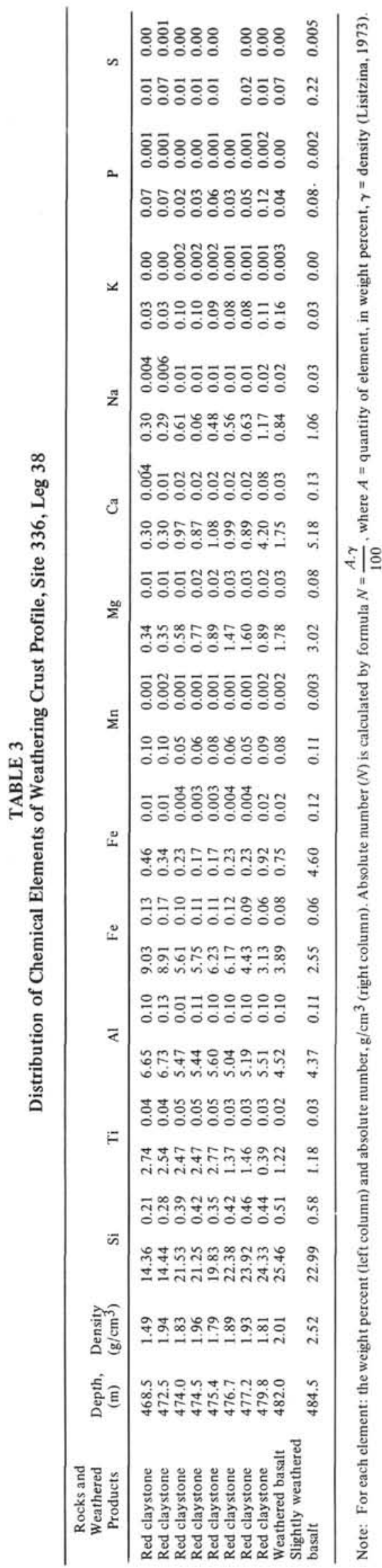

The mean basalt composition at Site 336 reduced to $100 \%$ of "dry" rock (Table 4) is similar to the mean tholeiite composition from the Mid-Atlantic Ridge (Engel et al., 1965). However, the data from the Mikhail Lomonosov 26 cruise (1972) indicate that alkalinity of the Iceland-Faeroe Ridge basalts increases in the direction from Site 336 to Iceland and to the Faeroe Islands. The $\mathrm{K}_{2} \mathrm{O}$ content increases from $0.20 \%$ to $0.80 \%$, the phosphorous content increases somewhat also. In general, the mean composition of Iceland Faeroe basalts is similar to traps of Iceland, Faeroe Islands, and the Isle of Skye (Table 4).

The increased alkalinity of basalts in the direction of Iceland is also observed on the Reykjanes Ridge (Schilling, 1973). Schilling attributes this to the alkaline magma evacuation by the Iceland mantle plume. Low basalt alkalinity in the middle part of the Iceland Faeroe Ridge appears to be realted to the Tertiary rift zone, an extension of the "extinct axis" (Vogt et al., 1970).

\section{EXTINCT AXIS}

Site 337 is located on the eastern flank of the southern extremity of the Norway seamounts near the assumed "extinct axis" of the Norway Basin. The series of volcanities, consisting of basaltic pillow lava flows, amygdaloidal basalts, and volcanic breccia horizons with glass and sedimentary rock interbeds were recovered at a depth of 113 to 132.5 meters below the sea floor. Overlying sediments are early or middle Oligocene.

Variolitic basalts and hyalobasalts, amygdaloidal variolitic hyalobasalts, and basaltic breccia were distinguished petrographically. Textural and structural properties are described in Site Report Chapter 3 (this volume). (See also Plate 1, Figures 3-6).

The modal mineral composition is given in Table 1. Based on the olivine content, one can distinguish olivine and nonolivine types of basalts and hyalobasalts. However, in most cases olivine is replaced by iddingsite, carbonate, and hydrobiotite. Fresh olivine $\left[\mathrm{Ng}(\gamma)=1.698, \mathrm{~Np}(\alpha)=1.660,2 \mathrm{~V}=\right.$ from $-86^{\circ}$ to $\left.90^{\circ}\right]$ is present in a thin section from Sample 13-1, 80-83 cm. Generally the basalts from Site 337 are irregularly crystallized. The amount of varioles, consisting of thin plagioclase laths with cleaved ends, differs at diverse horizons. They are very abundant in some parts, and the rock assumes a leucocratic appearance. The amount of pyroxene varies also. Pyroxene is largely replaced by hydrogoethite and hydromica. The phenocryst content is not constant. Melted phenocrysts of plagioclasebytownite (An 74) having $\mathrm{Ng}(\gamma)=1.574, \mathrm{~Np}(\alpha)=$ 1.565 are observed at times (Sample 13-1, 80-83 cm). Large plagioclase laths have the same composition. Sometimes (Sample 14-3, 8-11 cm) the basalt consists of varioles, glass, and plagioclase phenocrysts. Pyroxene crystallization has not taken place. Normative nepheline is present in small amounts (Table 1, Figure 9).

Secondary minerals are abundant, filling joints, cavities and vesicles, and forming veins and amygdules. They are especially abundant in breccia horizons which are probably transformed surfaces of lava 
streams. Angular fragments of volcanic glass are fully replaced by chlorite and smectite. Breccia cement also has a chlorite-smectite composition. Veins and amygdules consist of calcite and chlorite.

Material from cores showing slight secondary alterations were chosen for chemical analysis. Table 2 shows that the chemical composition of basalt is subject to some variations. This has probably resulted both from primary nonuniformities in the basaltic mineral composition and from secondary mineral transformations. Thus, low contents of silica and alumina (Sample 14-3, 128-131 cm) appear to be related to the basalt calcitization (about 13\% calcite). The inverse proportional ratio of calcium and aluminum (Figure 4) confirms this. The high content of potassium may be reiated to smectite.

For the potassium, sodium, and aluminum content, the mean basalt composition at Site 337 recalculated for $100 \%$ of "dry" rock is similar to that of Iceland, the Faeroe Islands, and the Isle of Skye (Table 4). However, the former is characterized by the low titanium content, typical of tholeiites from the Mid-Atlantic Ridge.

The subalkaline character of basalts cored at Site 337 may be explained by their presence on the top of a seamount. Numerous observations have shown these basalts are characterized by a high potassium content (Engel et al., 1965; Aumento, 1968).

\section{VØRING PLATEAU}

Two sites (338 and 342) located on the outer part of the $\mathrm{V} \phi$ ring Plateau contained basalts overlain by sediments of early Miocene (Site 342) and early Eocene (Site 338). A horizon of sandstones and breccia conglomerate with pebble and rock debris of weathered ferruginous basalts is present in the sedimentary cover at Site 338. Descriptions of the basalt unit are given in Site Report Chapters (this volume). See also Plate 2, Figures 1-4. More comprehensive petrographical characteristics and additional data on the mineral composition and secondary minerals are outlined here.

The textures of all basalts at Sites 338 and 342 are evidently porphyritic and glomeroporphyritic. The groundmass texture is nonuniform; microdoleritic combined with subophitic, microintersertal, pilotaxitic, tholeiitic, and poikilophytic. The phenocryst content reaches $25 \%-30 \%$. Based on the phenocryst composition, one can distinguish the following basalt types: (1) Olivine porphyritic basalts (338-42-2, 144-147 cm; 338$43-4,40-43 \mathrm{~cm} ; 338-44-3$, 48-51 cm; 342-8-1, 136-138 $\mathrm{cm})$; (2) Plagioclase porphyritic basalts (338-43-2, 41-44 $\mathrm{cm}$; 338-45-2, 128-131 cm; 342-7-4, 7-5, 8-3); (3) Plagioclase-pyroxene porphyritic basalts $(342$, Cores 7 $1,8-4)$; and (4) Glomeroporphyritic basalts (338-45, $131-133 \mathrm{~cm} ; 342-7-1,122-125 \mathrm{~cm} ; 7-3,91-93 \mathrm{~cm} ; 7-5,68-$ $71 \mathrm{~cm})$.

In some horizons, these basalts contain a large amount (more than 10\%) of amygdules, thus they can be referred to as amygdaloidal basalts. Phenocrysts of the intratelluric type are present. Phenocrysts and plagioclase glomeroporphyritic clusters are coarse (with length of 3-4 mm), of an irregular prismatic form, jointy, and poorly twinned. Under crossed nicols, the grains break down into irregular blocks becoming extinct at different times (a phenomenon of the prototectonic type). Plagioclase phenocrysts at Site 338 are more basic than those at Site 342 ; in the former they are An 62-69, in the latter, An 56-65.

Pyroxene augite phenocrysts consist of irregular prismatic grains and clusters with about a 1-mm length. Poikilophytic plagioclase inclusions are often present in them. Augite having $+2 \mathrm{~V}=$ from $34^{\circ}$ to $64^{\circ}, \mathrm{C}: \mathrm{Ng}(\gamma)$ $=$ from $34^{\circ}$ to $57^{\circ}$ are present in the basalts at Site 338 . Measurements of these components taken along a basalt unit profile do not illustrate regular pattern of alterations (Tables 5,6). Together with clinopyroxene at Site 338 there is orthopyroxene (Core 45-1) having $+2 \mathrm{~V}=58^{\circ}-70^{\circ}$ and $\mathrm{C}: \mathrm{Ng}(\gamma)=4^{\circ}-14^{\circ}, \mathrm{Ng}(\gamma)-\mathrm{Np}(\alpha)$ $=0.008$. There was probably orthopyroxene in the basalts at Site 342, but it is now completely replaced by aggregates of hydrobiotite-chlorite. Augite (342) is slightly lilac colored which suggests the presence of titanium (titanaugite). Olivine phenocrysts are very abundant (up to $20 \%$ ), but they are wholly replaced by iddingsite and calcite aggregates, maintaining the form of the original olivine crystals (Site 338).

Secondary mineral alterations of the V $\phi$ ring Plateau basalts are considerably less in comparison with those from the Norway Seamounts. The alterations are more strongly developed at Site 338 than at Site 342 . Secondary minerals (calcite, chlorite) develop as veins and fill hollows. As noted above, olivine is completely replaced by iddingsite, calcite, and goethite. Pyroxene is partly replaced by hydrobiotite and goethite. In joints, plagioclase is replaced by hydromica, calcite, and chlorite. Volcanic glass is replaced by chlorite and smectite. The content of secondary minerals is usually small, (about 10\%-15\%).

An important property of basalts at Site 342 is the presence of fine $(0.1-1.0 \mathrm{~mm})$ impregnations of native copper. Similar cupreous basalts, dolerite basalts, and dolerites were found on the Icelandic-Faeroe Ridge (Kharin, in press).

Chemically the basalts of the V $\phi$ ring Plateau, in contrast to tholeiites of the Mid-Atlantic Ridge, have a higher alkalinity, especially basalts at Site 342 . The high content of titanium observed here is in agreement with the presence of titanaugite. The graph of $\mathrm{K}_{2} \mathrm{O}+\mathrm{Na}_{2} \mathrm{O}$ dependence on the ferruginous coefficient (Figure 6) shows that the largest variations are inherent to basalts of Site 338. This can be accounted for by crystallization differentiation which produced the different content of pyroxene and olivine. The differentiation is confirmed by the direct proportional relationship of $\mathrm{CaO}$ and $\mathrm{Al}_{2} \mathrm{O}$ (Figure 4). The average composition of the $\mathrm{V} \phi \mathrm{r}$ ing Plateau basalts is closer to plateau basalts of Iceland, Faeroe Islands, and Isle of Skye than to tholeiites of the Mid-Atlantic Ridge (Table 4). Basalts of Site 342 are especially close to plateau basalts.

\section{LOFOTEN BASIN}

Alkaline and subalkaline basalts were cored from Site 343, at the eastern part of the Lofoten Basin at the foot of the Voring Plateau outer slope. Basalts are present as thin sills in marine sediments of early Eocene age. 

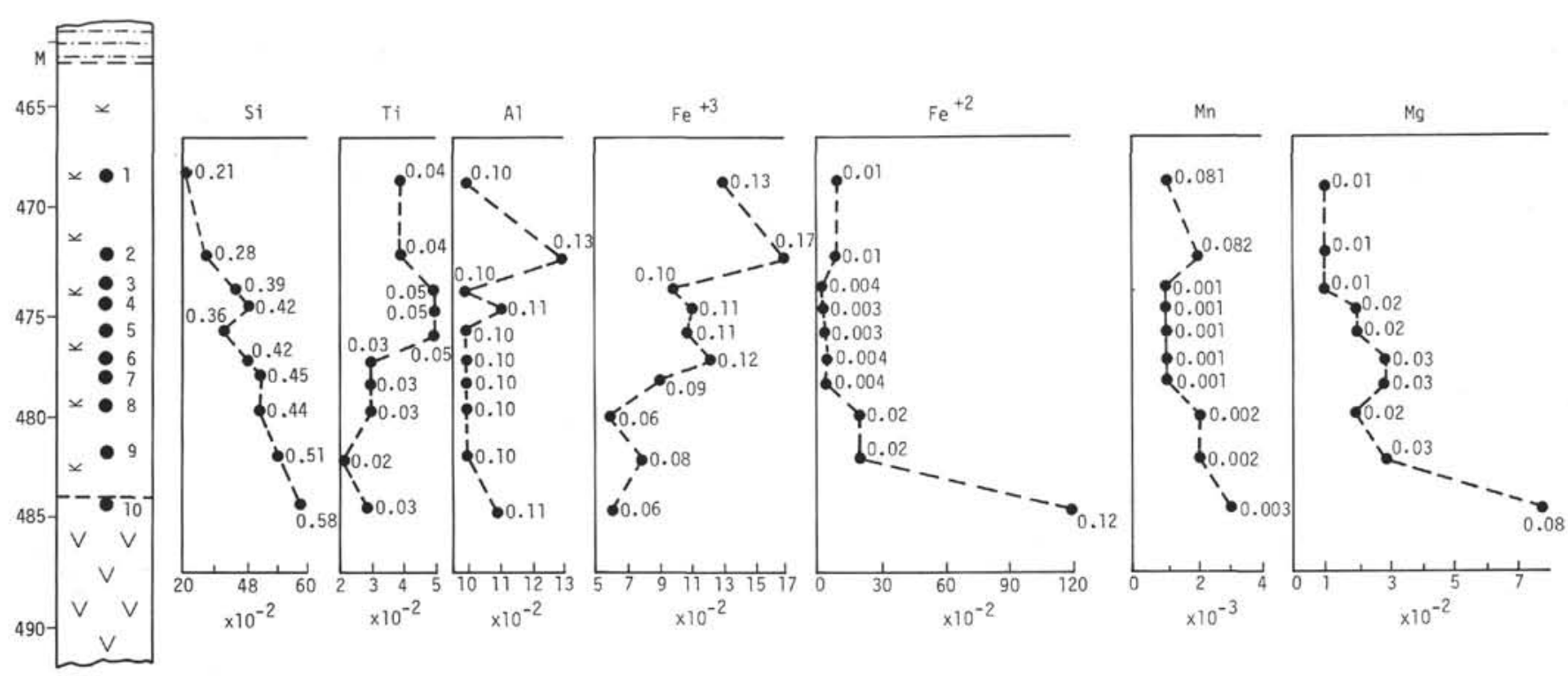

Figure 2. Distribution of chemical elements in the weathering crust profile, Site 336.

The boundary between the V $\phi$ ring Plateau and Lofoten Basin is a tectonic fracture according to seismic data. Basalts and enclosing rocks of Site 343 are essentially affected by this fracture; they are speckled by numerous joints and slickensides, and mylonitized and pyritized to such a degree that some basalt areas look like an attrition clay (Plate 2, Figure 5,6).

Five basalt sills were cored. Sedimentary rocks are metemorphosed at the contact with basalts. Dolomitization and phosphatization of limestones is also noted. Limestones are strongly lithified near contacts compared with overlying Eocene sediments. Basalts near contacts are slightly crystallized, contain a great deal of glass, and have a hyaloophytic structure. In the middle of the sills, the basalts are better crystallized, often they are holocrystalline and have a subdoleritic structure. Quick cooling at contacts has produced plagioclase crystallization. However, pyroxene and olivine were not crystallized.

Plagioclase is present in the mass of devitrified glass, and forms idiomorphic laths of a uniform size $(0.8 \times$ $0.08 \mathrm{~mm}$ ). The laths consist of andesine (An 47), and being twinned, form a pronounced framework. Finer laths and plagioclase microlites are present in gaps between laths. Pyroxene consists of scarce grain aggregates and underdeveloped crystals.

Volcanic glass (up to $30 \%$ ) is entirely replaced by chlorite, smectite, and hydromica (hydrobiotite). A great deal of leucoxene is present, and minerals (ilmenite) make up separate crowdings and chains. There is an abundance of disordered amygdules (up to $30 \%)$. Usually, they are fine $(0.1-1 \mathrm{~mm})$, rounded-oval, of an irregular form, and filled by hydrobiotite, chlorite, calcite, and sometimes pyrite.

Basalts in the centers of sills have a porphyritic and microporphyritic texture with a hyalo-ophytic, intersertal, and variolitic groundmass. Their structure is taxitic, amygdaloidal. Monoclinic pyroxene (10\%-20\%) is poorly crystallized, forming irregular grains and grain crowdings. Rare olivine is entirely replaced by secondary minerals. Plagioclase consists of large $(1.3 \times 0.3$ $\mathrm{mm}$ ) laths with pronounced zoning. A peripheral border of zonal crystals is narrow and transparent. Its composition complies with andesine (An 45), however, microlites in the groundmass consist of labradorite (An 56).

Petrographic study of basalt samples (in immersion) and measurements of refractive indexes show that albite (up to $5 \%$ ) and perhaps common potash feldspar are present. Magnetite (up to $15 \%-20 \%$ ) constitutes fine grains. Volcanic glass is fully replaced by chlorite, smectite, and hydromica.

Five samples from cores subjected to the least secondary alterations were chosen for a chemical analysis. The data of both chemical and mineralogical analyses confirm increased alkalinity and a high content of titanium, iron, and sodium. High alkalinity (up to $2.96 \% \mathrm{~K}_{2} \mathrm{O}$ ) is not related to secondary alterations (Figure 3) but is a result of differentiation processes. However, albitization and the high sodium content are due to secondary processes of the spilitic type.

The average chemical composition differs from that of the Mid-Atlantic Ridge tholeiites and is similar to the average chemical composition of alkali basalts developed in transform fracture zones (Kharin and Bogdanov, 1974). Similar alkali basalts are present in a transform fracture of the Jan-Mayen Ridge (based on the data of R.V. Akademik Kurchatov, 10th cruise).

\section{MOHNS RIDGE}

Altered basalt (tuff) breccia was drilled at Site 345, at depths of 762 to 774.5 meters below the sea floor, in the eastern part of the Mohns Ridge, at the boundary with the Lofoten Basin. Alkali basalts are present below to 802 meters. The megascopic and brief petrographic description of basalt breccia and basalts is given in Site Report Chapter 6, (this volume). See also Plate 4, Figures 3-6. Additional data on petrographical features, mineral composition, and chemistry are noted here.

The breccia thickness is 12.5 meters with 13 indistinct rhythms with a thickness from 0.3 to 1.0 meters being 

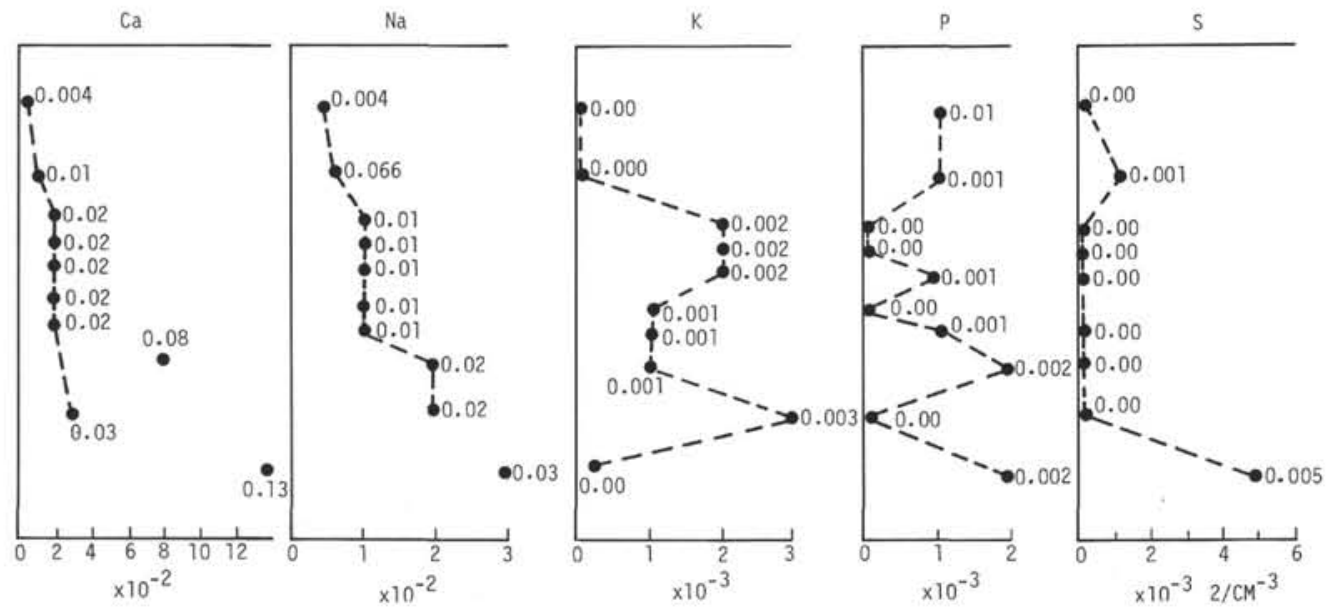

Figure 2. (Continued).

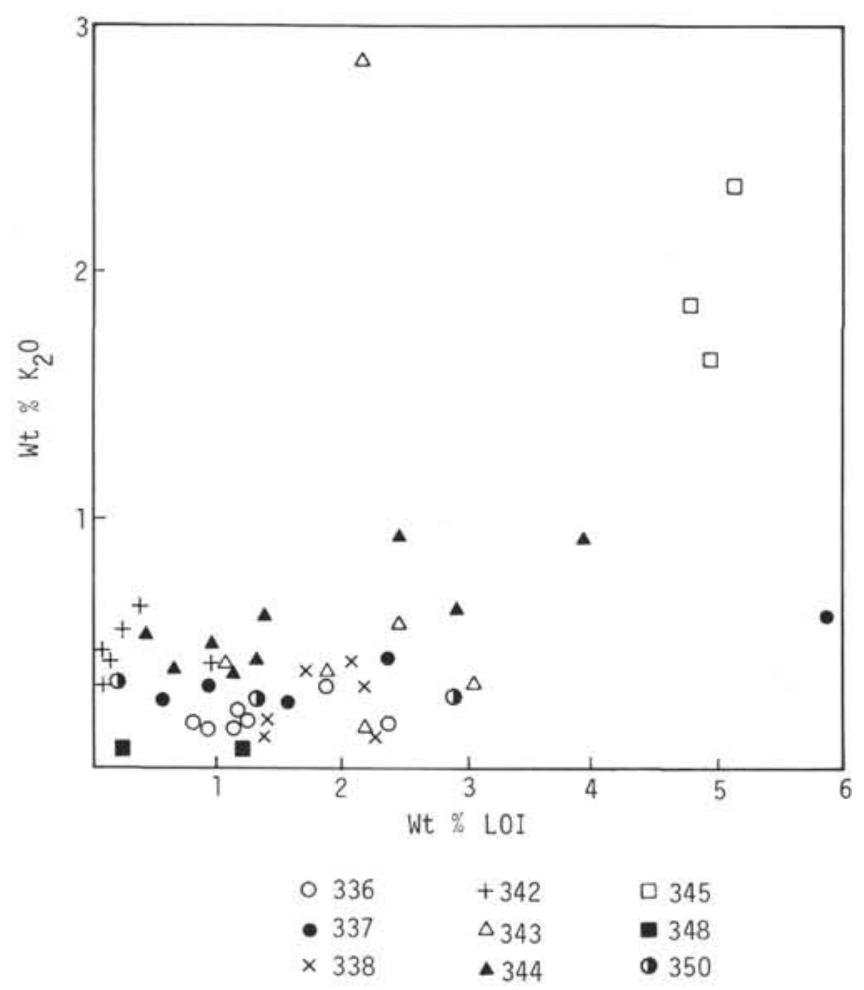

Figure 3. Correlation of $\mathrm{K}_{2} \mathrm{O}$ with LOI in magmatic rocks from Leg 38.

distinguished. Rudaceous tuff breccias are present at the base of each rhythm. The fragment size gradually decreases towards the rhythm top. Olivine basalts comprise the coarse breccia fragments, with basalt ferruginization (hematitization) being observed. Small fragments consist of dark green and light green chlorite, smectite, and sometimes zeolite. Some fragments appear to be transformed volcanic glass and hyalobasalts. Distinct banding on fragments is consistent with different replacement stages by secondary minerals. Study of fragments in immersion slides has shown that: (1) (Sample 33-3, 10-12 cm) they consist of

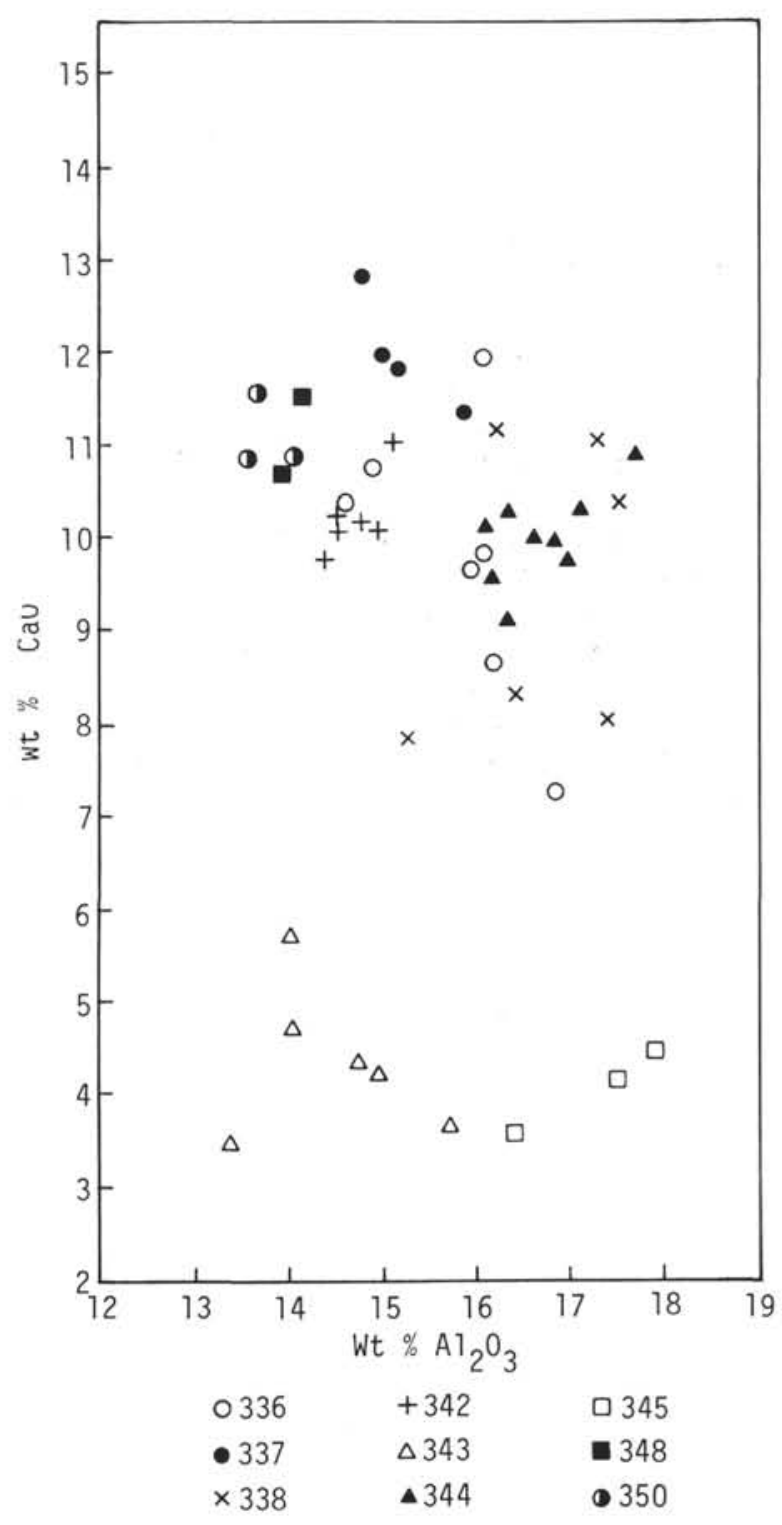

Figure 4. Correlation of $\mathrm{CaO}$ with $\mathrm{Al}_{2} \mathrm{O}_{3}$ in magmatic rocks from Leg 38. 


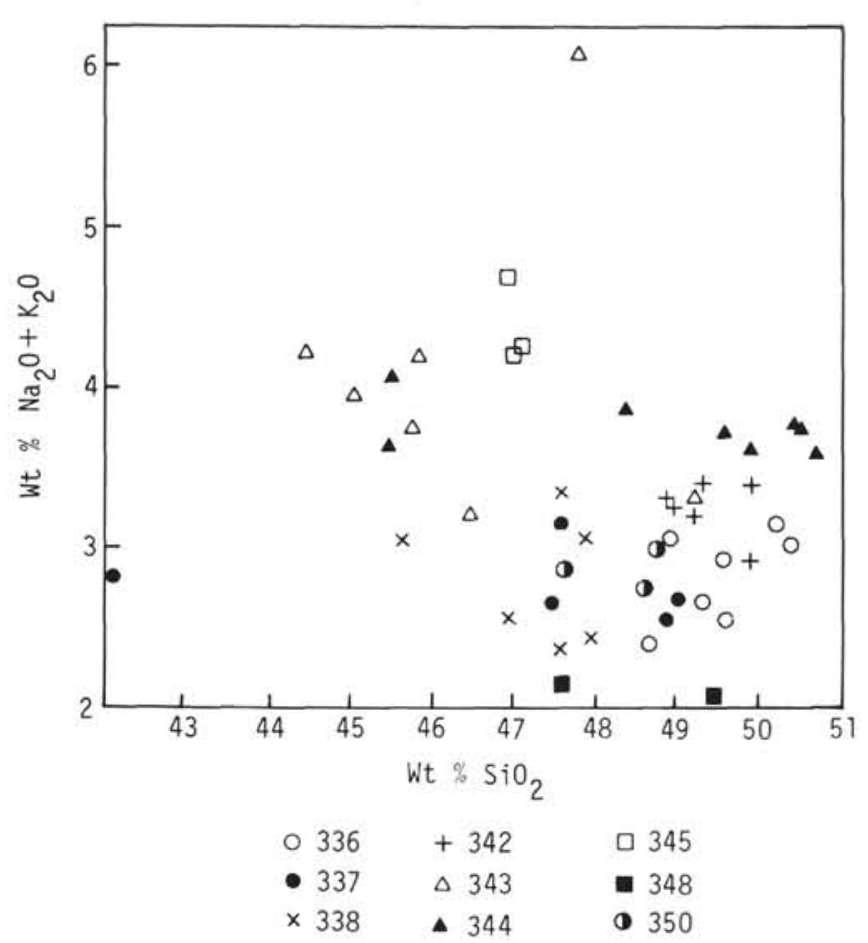

Figure 5. Correlation of $\mathrm{Na}_{2} \mathrm{O}+\mathrm{K}_{2} \mathrm{O}$ with $\mathrm{SiO}_{2}$ in magmatic rocks from Leg 38.

chlorite, its refractive index changing from 1.570 to 1.658 in different bands; and (2) (Sample 33-1, $95 \mathrm{~cm}$ ) the fragments consist of smectite $(N=1.555-1.560)$. There are inclusions of calcite probably replacing plagioclase.

Breccia cement consists of a finely dispersed, in some parts nearly isotropic, matrix with $N=1.520-1.536$ (saponite). However, there are parts consisting of a matrix with $N=1.500$ (zeolite), and parts with $N=$ 1.50-1.560 (allophane). Calcitization of breccia fragments and cement is observed. A hematite vein crossing the breccia was seen in one case (Sample 33-2, $130-135 \mathrm{~cm})$. Thin interbeds of sedimentary-tuff breccia and sandstones with radiolarians are sometimes present in the tuff breccia (Core 33, depth $767.2 \mathrm{~m}$ ). A high content of quartz grains is observed in the sandstones; the content in tuff breccia is lower.

Petrographically the basalts at Site 345 are divided into two types: altered hyalobasalts and amygdaloidal basalts.

The texture of hyalobasalts is porphyritic. The groundmass is microhyaloophytic, ophytic, and intersertal. Their structure is taxitic and amygdaloidal. There are few phenocrysts (10\%-15\%), and very often they consist of plagioclase. Pyroxene had not had time to be crystallized, and is present only in well-crystallized parts in hyalobasalts. Olivine, fully replaced by secondary minerals, is also rarely present. Plagioclase forms prismatic crystals (with length to $1 \mathrm{~mm}$ ) and laths $(1.0 \times 0.3 \mathrm{~mm})$. Measurements of refractive indexes $\mathrm{Ng}^{\prime}\left(\gamma^{\prime}\right)=1.568, \mathrm{~Np}^{\prime}\left(\alpha^{\prime}\right)=1.560$ indicate that plagioclase are labradorite (An 62). Zonal plagioclase consists of bytownite (An 73), with $\mathrm{Ng}(\gamma)=1.574$ in the center and of andesine-labradorite (An 50) with Np $=1.553$ in the periphery. The central part of such phenocrysts are often replaced by compact scaly hydromica aggregates.

The form of amygdules $(0.1-1.0 \mathrm{~mm})$ is rounded-oval and irregular. They are filled by greenish smectite and white calcite. An ore mineral is present, irregularly distributed in accordance with the taxitic structure. It is generally present in round amygdules. The fine-tabular ore mineral of the titanomagnetitic type is accumulated around plagioclase laths and microlites forming microdendritic aggregates.

The groundmass is altered glass with secondary minerals of chlorite and smetite. Rims resembling quenching zones border amygdules in the groundmass, suggesting quick chilling of the magma.

The texture of the amygdaloidal basalts is porphyritic. The groundmass is microintersertal, hyaloophytic, and ophytic. The structure is amygdaloidal. As opposed to the hyalobasalts, colored minerals did not have time to crystallize. However, their amount is small and they are replaced by secondary minerals. Pyroxene

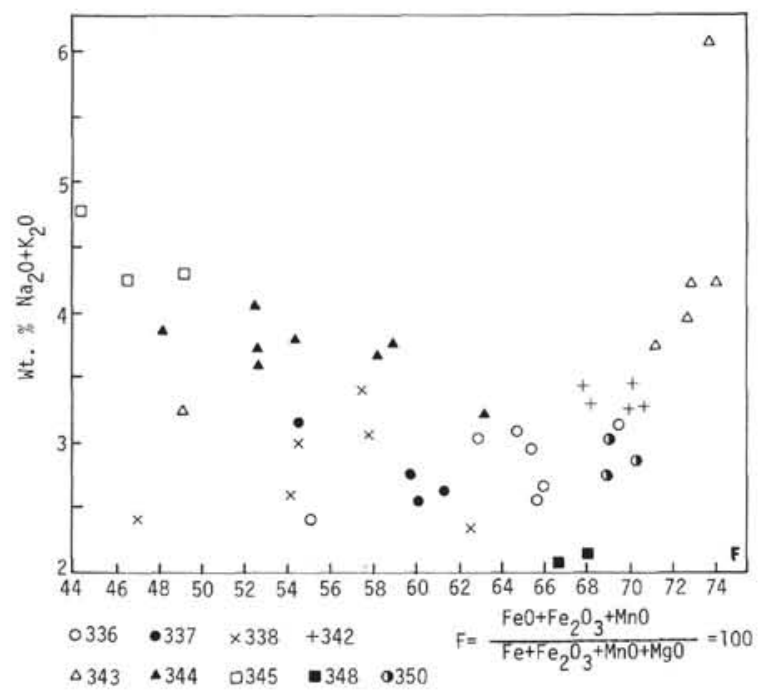

Figure 6. Correlation $\mathrm{Na}_{2} \mathrm{O}+\mathrm{K}_{2} \mathrm{O}$ with coefficient iron in magmatic rocks from Leg 38. 


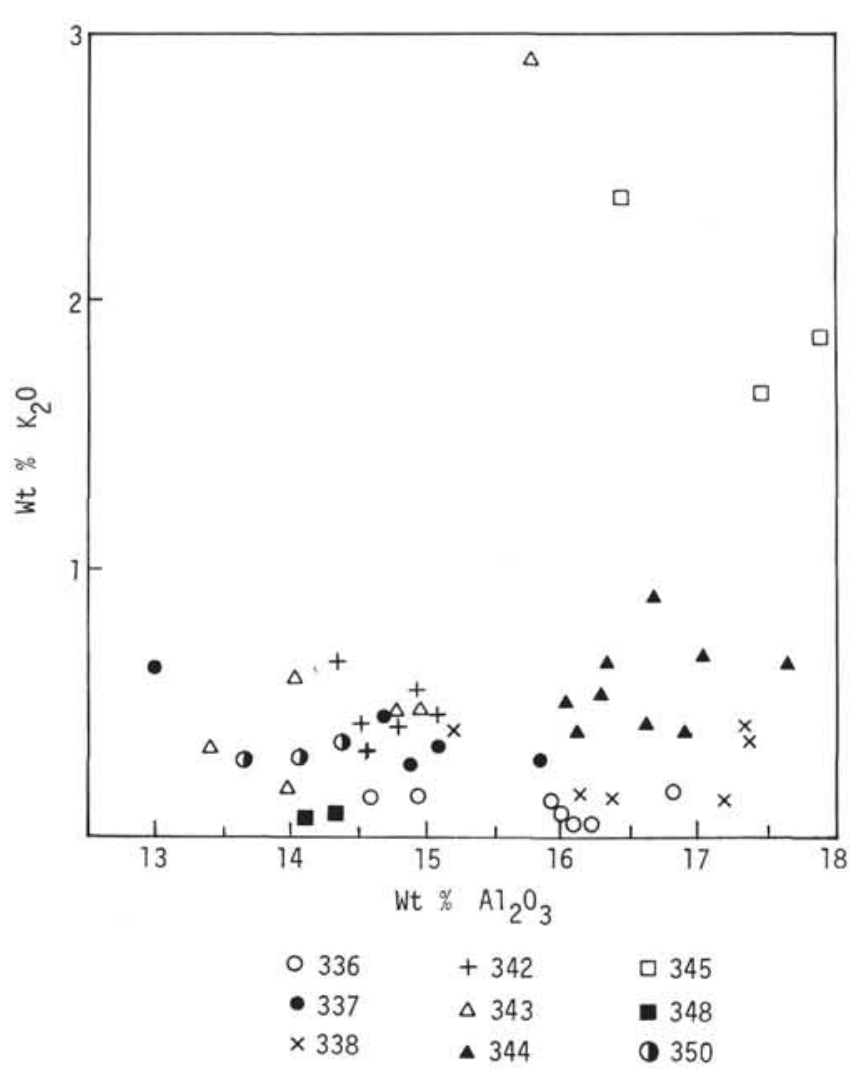

Figure 7. Correlation of $\mathrm{K}_{2} \mathrm{O}$ with $\mathrm{Al}_{2} \mathrm{O}_{3}$ in magmatic rocks from Leg 38.

is replaced by chlorite and hydrogoethite, olivine by calcite and hydrogoethite. The glassy groundmass has numerous fine plagioclase laths. The glass is replaced by chlorite and smectite. There is much ore rash (goethite-hydrogoethite) and leucoxene. Leucoxene forms pseudomorphic plates and small earthy accumulations. Less crystallized parts of the basalt have more pores and amygdules. The amount of ore minerals is higher here, compared with more holocrystallized basalt. Amygdules consist of smectite aggregates or calcite monocrystals.

The chemical data (Table 2) show that the chemical composition of the tuff breccia and the basalts is rather similar. Only the tuff breccia at the top (Sample 32-3, $60-63 \mathrm{~cm}$ ) is characterized by a low silica content, related to the high calcite content in the breccia cement. It is noteworthy that both the tuff breccia and basalts are highly potassic, the $\mathrm{Na}_{2} \mathrm{O} / \mathrm{K}_{2} \mathrm{O}$ ratio is close to 1 . The high potassium content appears to be partly due to secondary minerals, especially smectite. However, there is no direct relationship between secondary alterations and the potassium content (Figure 3 ).

The basalts are alkaline, and a study of immersion slides makes it possible to identify grains resembling alkaline feldspar. The average composition of "dry" basalt from Site 345 is close to that of a basalt rich in alkali (Engel et al., 1965) differing from the low sodium and calcium content and the high magnesium content.

Usually alkali basalts are observed on islands, seamount tops, and in transform fracture zones of midoceanic ridges. The tectonic position of Site 345 is at the possible intersection of the Jan-Mayen Fracture Zone with the fracture separating the Mohns Ridge from the Lofoten Basin. This is probably the reason for the high alkalinity of the basalt magma which became elevated from deeper mantle horizons than the tholeiitic basaltic magma.

\section{KNIPOVICH RIDGE}

Magmatic rocks of the gabbro-basaltic group were cored at Site 344 on the eastern flank of the Knipovich Ridge, under glacial-marine sediments, at a depth of 377.5 to 414 meters below the sea floor.

Megascopic and microscopic study has made it possible to distinguish three principal types of magmatic rocks: diabase (dolerite), gabbro-diabase (gabbrodolerite), and gabbro (Plate 3, Figures 1-6 and Plate 4, Figure 1,2). The modal mineral compositions of the rock types distinguished are similar. There are some differences in the composition of the secondary

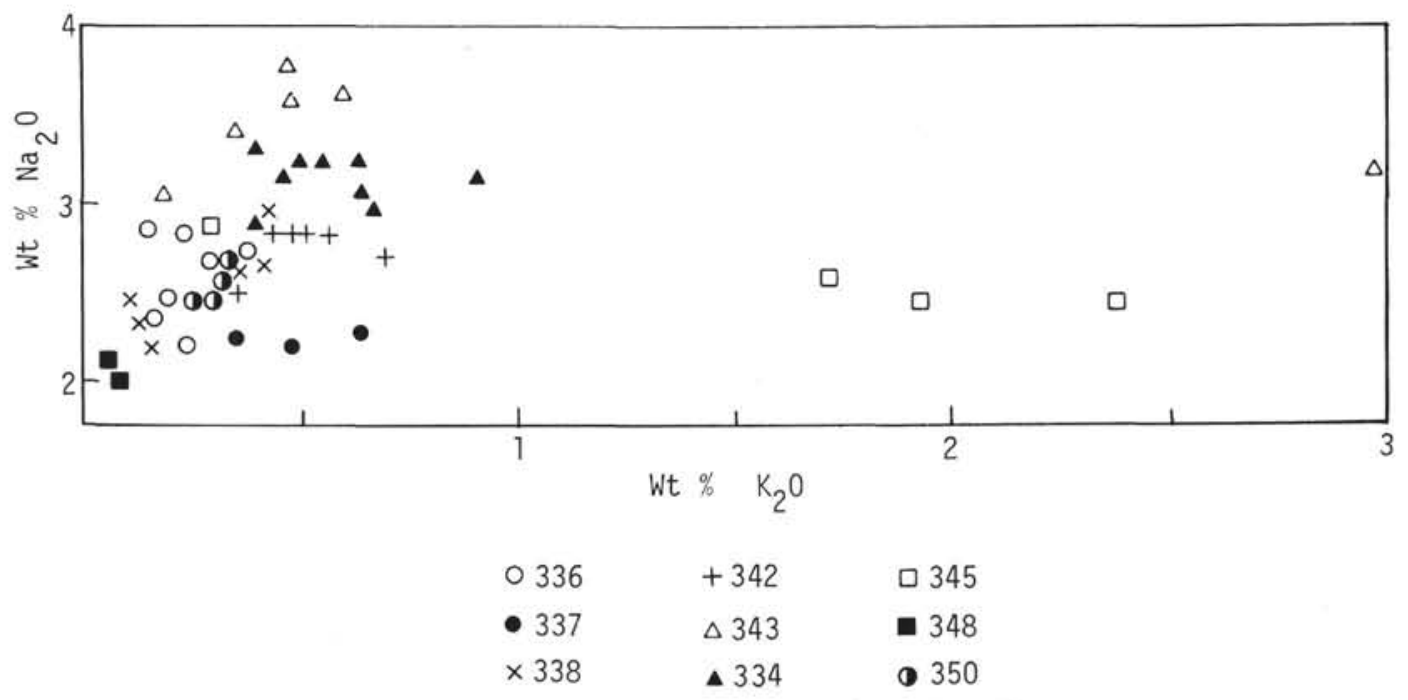

Figure 8. Correlation of $\mathrm{Na}_{2} \mathrm{O}$ and $\mathrm{K}_{2} \mathrm{O}$ in magmatic rocks from Leg 38 . 
TABLE 4

Comparison of Chemical Composition of Basalt of Leg 38 with Basalts of Other Oceanic and Continental Regions

\begin{tabular}{|c|c|c|c|c|c|c|c|c|c|c|}
\hline & $\begin{array}{c}\text { Samples } \\
336-40, \mathrm{CC} \\
\text { to } \\
336-44-2, \\
105-108 \\
\mathrm{~cm}\end{array}$ & $\begin{array}{c}\text { Samples } \\
337-13-1 \text {, } \\
80-83 \mathrm{~cm} \\
\text { to } 15-1 \text {, } \\
127-130 \\
\mathrm{~cm}\end{array}$ & $\begin{array}{c}\text { Samples } \\
338-42-2 \text {, } \\
144-147 \\
\text { cm to } \\
338-45-2 \text {, } \\
47-50 \mathrm{~cm}\end{array}$ & $\begin{array}{c}\text { Samples } \\
342-7-2 \text {, } \\
40-43 \\
\mathrm{~cm} \text { to } \\
342-8-3 \text {, } \\
137-140 \\
\mathrm{~cm}\end{array}$ & $\begin{array}{c}\text { Samples } \\
343-12-2 \text {, } \\
140-143 \\
\mathrm{~cm} \text { to } \\
343-16-3 \\
144-147 \\
\mathrm{~cm}\end{array}$ & $\begin{array}{c}\text { Samples } \\
344-34-1 \text {, } \\
114-117 \\
\mathrm{~cm} \text { to } \\
344-37-3 \\
135-137 \\
\mathrm{~cm}\end{array}$ & $\begin{array}{c}\text { Samples } \\
345-34-2 \text {, } \\
128-131 \\
\mathrm{~cm} \text { to } \\
345-35-3 \text {, } \\
128-131 \\
\mathrm{~cm}\end{array}$ & $\begin{array}{c}\text { Samples } \\
348-33-2 \text {, } \\
143-146 \\
\mathrm{~cm} \text { to } \\
348-34-2 \text {, } \\
146-149 \\
\mathrm{~cm}\end{array}$ & $\begin{array}{c}\text { Samples } \\
350-16-1 \text {, } \\
114-117 \\
\mathrm{~cm} \text { to } \\
350-16-3, \\
101-103 \\
\mathrm{~cm}\end{array}$ & 1 \\
\hline $\mathrm{SiO}_{2}$ & 50.42 & 48.41 & 48.35 & 49.58 & 47.18 & 50.28 & 49.57 & 49.29 & 49.20 & 48.23 \\
\hline $\mathrm{TiO}_{2}$ & 1.81 & 1.40 & 1.46 & 2.87 & 3.12 & 1.54 & 2.10 & 1.65 & 2.63 & 2.10 \\
\hline $\mathrm{Al}_{2} \mathrm{O}_{3}$ & 16.04 & 15.11 & 16.99 & 14.72 & 14.87 & 17.08 & 18.18 & 14.46 & 14.23 & 15.54 \\
\hline $\mathrm{Fe}_{2} \mathrm{O}_{3}$ & 6.16 & 5.76 & 5.91 & 4.85 & 10.25 & 3.70 & 5.76 & 5.35 & 4.24 & 5.05 \\
\hline $\mathrm{FeO}$ & 5.88 & 5.55 & 5.50 & 8.11 & 7.44 & 5.06 & 3.97 & 8.65 & 8.97 & 7.49 \\
\hline $\mathrm{MnO}$ & 0.21 & 0.18 & 0.19 & 0.22 & 0.56 & 0.20 & 0.31 & 0.30 & 0.27 & 0.20 \\
\hline $\mathrm{MgO}$ & 6.54 & 7.54 & 8.91 & 5.79 & 7.36 & 7.85 & 10.81 & 6.98 & 6.06 & 7.20 \\
\hline $\mathrm{CaO}$ & 9.92 & 13.04 & 9.68 & 10.32 & 4.51 & 10.27 & 4.30 & 11.03 & 11.16 & 11.04 \\
\hline $\mathrm{Na}_{2} \mathrm{O}$ & 2.65 & 2.45 & 2.60 & 2.80 & 3.53 & 3.23 & 2.57 & 2.08 & 2.62 & 2.46 \\
\hline $\mathrm{K}_{2} \mathrm{O}$ & 0.23 & 0.42 & 0.29 & 0.48 & 0.85 & 0.59 & 2.11 & 0.08 & 0.32 & 0.42 \\
\hline $\mathrm{P}_{2} \mathrm{O}_{5}$ & 0.14 & 0.14 & 0.11 & 0.26 & 0.33 & 0.20 & 0.32 & 0.13 & 0.30 & 0.27 \\
\hline Total & 100.00 & 100.00 & 100.00 & 100.00 & 100.00 & 100.00 & 100.00 & 100.00 & 100.00 & 100.00 \\
\hline
\end{tabular}

Note: 1 - basalt of Faeroe-Iceland ridge (average of 11 analyses, Kharin); 2 - basalt of Jan Mayen fracture zone (average of 6 analyses, Kharin); 3 - basalt of Kolbeinsey (Iceland - Jan Mayen) ridge (average of 9 analyses, Kharin); 4 - basalt of Reykjanes ridge (average of 9 analyses, Kharin); 4 - basalt of Reykjanes ridge (average of 11 aralyses, Kharin); 5 - basalt of Romanche fracture zone (average of 4 11 analyses, Kharin); 5 - basalt of Romanche fracture zone (average of 4 analyses, Kharin, Bogdanov, 1974); 6 - Tertiary plateau-basalt of East Iceland (average of 22 analyses, Baskina, 1971); 7 - Tertiary basalt of Faeroe Islands (average of 18 analy ses, Noe-Nygaard,

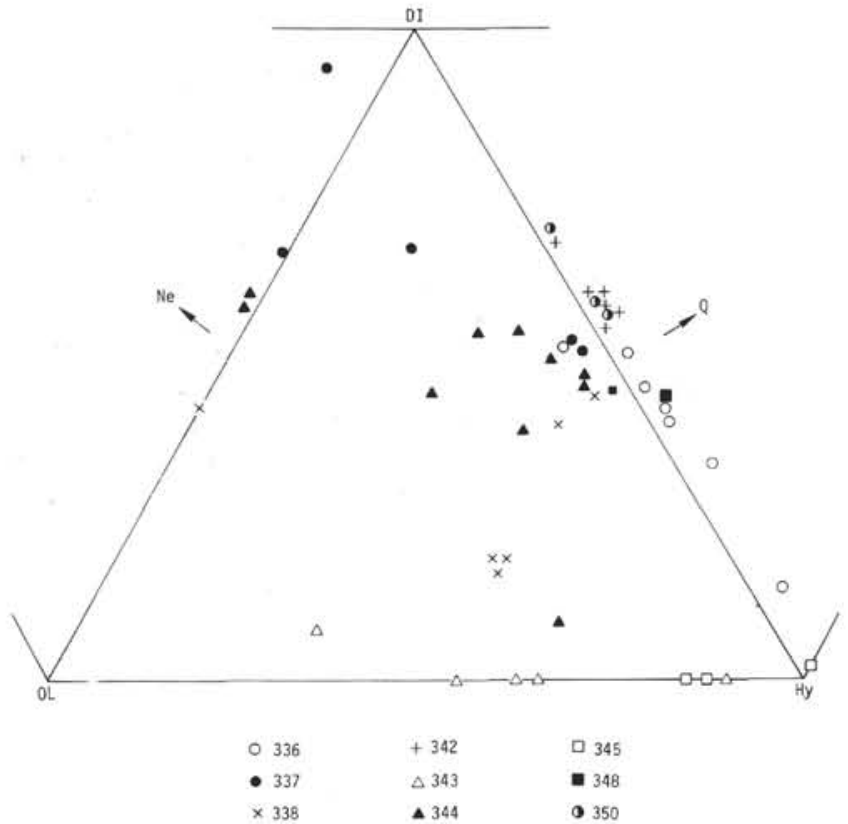

Figure 9. Triangular diagram of weight of normative diopside, olivine, and hypersthene in magmatic rocks from Leg 38.

minerals, which sometimes affect the primary mineral composition. All rocks are characterized by a rather intensive pyritization, and by the presence of primary biotite with hydrobiotite on the pyrite. The pyrite content ranges from $3 \%$ to $5 \%$. Clinopyroxene has alkalescent properties and approaches titanium-augite. There is the high content of accessories, especially apatite. These data suggest a subalkaline composition for the primary basalt magma.
The rock texture and structure are more variable, unlike the mineral composition. The granularity (from fine to coarse-crystalline) noticeably changes quickly; however, samples are holocrystalline. Only in single thin sections can one suggest the presence of some glass entirely replaced by chlorite. The rock texture is often ophitic and subophitic, with poikilophitic elements. The hypidiomorphic-granular texture characteristic of gabbro is rarely present. The taxitic nonuniformity of the rock is seen both visually and petrographically. Fine-grained and coarse-grained parts have nearly the same minerals components. However, sometimes one can see some parts with the pronounced nonuniform texture and taxitic structure which resulted from the irregular distribution of rock-forming minerals and irregular crystallization.

The subophitic texture predominates here. It contains relatively coarse (to $3.5 \times 1.0 \mathrm{~mm}$ ) plagioclase laths (An 65) oriented at an angle to each other uniformly over the whole rock. The taxitic structure is governed by the further crystallization occurring in different ways: some parts consist of one or several grains of clinopyroxene densely dissected by plagioclase laths. The form of pyroxene grains and plagioclase laths and their mutual arrangement suggest nearly concurrent formation; other parts of the rock are appreciably leucocratic. Intervals between plagioclase laths are filled by a microlitic felt of plagioclase and probably by glass remains. It is notable that such parts are considerably altered. They are greenish-yellow under the translucent light, and volcanic glass and microlitic felt with chlorite and hydromica developed over them are subjected to replacement.

Detailed study of plagioclase and pyroxene with measurements of refractive indexes in immersion slides, angles of extinction, and the $2 \mathrm{~V}$ on the Fedorov stage 


\begin{tabular}{|c|c|c|c|c|c|c|c|c|c|c|c|c|c|}
\hline 2 & 3 & 4 & 5 & 6 & 7 & 8 & 9 & 10 & 11 & 12 & 13 & 14 & 15 \\
\hline 48.73 & 49.48 & 49.15 & 46.96 & 48.42 & 49.30 & 47.24 & 49.80 & 49.31 & 49.34 & 50.83 & 50.19 & 49.22 & 50.22 \\
\hline 1.90 & 1.66 & 2.23 & 1.87 & 2.66 & 2.80 & 1.84 & 1.33 & 1.39 & 1.49 & 2.03 & 0.75 & 1.48 & 1.66 \\
\hline 16.31 & 14.94 & 14.24 & 15.63 & 13.49 & 13.50 & 15.73 & 16.87 & 16.15 & 17.04 & 14.07 & 17.58 & 15.18 & 15.60 \\
\hline 3.58 & 2.31 & 2.11 & 10.23 & 4.29 & 5.40 & 1.86 & 2.07 & 2.41 & 1.99 & 2.88 & 2.84 & 3.18 & 5.08 \\
\hline 7.16 & 10.14 & 11.36 & 5.20 & 9.49 & 8.70 & 10.63 & 7.28 & 6.79 & 6.82 & 9.06 & 7.19 & 9.32 & 6.91 \\
\hline 0.22 & 0.24 & 0.24 & 0.17 & 0.16 & 0.20 & 0.20 & 0.16 & 0.16 & 0.17 & 0.18 & 0.25 & 0.20 & 0.18 \\
\hline 7.06 & 7.13 & 6.99 & 6.19 & 10.71 & 11.00 & 9.17 & 11.38 & 7.99 & 7.19 & 6.34 & 7.39 & 6.22 & 4.65 \\
\hline 11.22 & 11.28 & 10.75 & 8.46 & 6.35 & 5.90 & 9.70 & 8.01 & 11.78 & 11.72 & 10.42 & 10.50 & 10.47 & 8.10 \\
\hline 2.64 & 2.18 & 2.50 & 3.74 & 2.52 & 2.50 & 2.94 & 2.78 & 2.82 & 2.73 & 2.23 & 2.75 & 2.22 & 2.92 \\
\hline 0.82 & 0.44 & 0.21 & 1.29 & 0.44 & 0.40 & 0.48 & 0.18 & 0.26 & 0.16 & 0.82 & 0.40 & 0.75 & 1.32 \\
\hline 0.36 & 0.20 & 0.22 & 0.26 & 0.38 & 0.30 & 0.22 & 0.14 & & & & & 0.15 & \\
\hline 00.00 & 100.00 & 100.00 & 100.00 & & & & & & & & & & \\
\hline
\end{tabular}

1966); 8 - Eocene basalt of Isle of Skye (average of 14 analyses, Tompson et al., 1972); 9 - oceanic tholeiite of Mid-Atlantic ridge (Engel et al., 1968); 10 - oceanic tholeiite (average of 150 analyses, Dmitriev, 1974); 11 - oceanic tholeiite (Engel et al., 1965); 12 - tholeiite (Nockolds, 1954); 13 - high alumina basalt (Kuno, 1960); 14 - traps of ancient shield areas (Kutolin, 1972); 15 - traps of young shield areas (Kutolin, 1972).

TABLE 5

Variations of the Pyroxene Angles in the Basalt Drilled at Site 338

\begin{tabular}{lccl}
\hline $\begin{array}{c}\text { Sample } \\
\text { Interval in cm) }\end{array}$ & $\begin{array}{c}(+) 2 \mathrm{~V} \\
(0)\end{array}$ & $\begin{array}{c}\mathrm{C}: \mathrm{Ng} \\
(\mathrm{C}: \gamma)\end{array}$ & \\
\hline (0) & Type of Pyroxene \\
$42-2,147-150$ & 60 & 42 & Augite \\
$43-4,115-118$ & 54 & 42 & Augite \\
$43-4,79-57$ & 58 & 43 & Augite \\
$43-4,79-82$ & 56 & 47 & Augite \\
$44-3,143-146$ & 42 & 34 & Pigeonite-augite \\
$44-3,143-146$ & 62 & 48 & Pigeonite-augite \\
$45-1,88-91$ & 70 & 12 & Enstatite \\
$45-1,88-91$ & 55 & 14 & Enstatite \\
$45-1,92-95$ & 74 & 4 & Enstatite \\
$45-1,92-85$ & 52 & 54 & Augite \\
\hline
\end{tabular}

showed that their composition varies slightly over the whole section at Site 344 (Tables 1 and 6). Plagioclase, forming coarse laths, has a labradorite-andesine composition (An 48-50) with $\mathrm{Ng}(\gamma)=1.561, \mathrm{~Np}(\alpha)=1.553$ in the upper part of the magmatic body (Sample 34-1, $114-117 \mathrm{~cm}$ ). In the middle and lower body parts (Cores 36-37), plagioclase is more basic (An 60-68). There is the zonal plagioclase with a labradorite composition (An 69) in the center and oligoclase (An 15) in the periphery. The idiomorphism degree of plagioclase crystals is different, which indicates that plagioclase crystallization occurred at different times. Secondary alterations of plagioclase are also different. Some laths are fully replaced by chlorite, hydromica, calcite, and rarely pyrite. Others are nearly fresh. Very often clinopyroxene forms less idiomorphic crystals compared with plagioclase; however, in some taxitic parts their idiomorphism degree is uniform. The pyroxene is greenish-yellow and pale lilac colored suggesting a relationship to titanium. The $2 \mathrm{~V}$ angle ranges from
TABLE 6

Variations of the Pyroxene Angles in the Gabbro-Diabase Body Drilled at Site 344

\begin{tabular}{lccl}
\hline $\begin{array}{c}\text { Sample } \\
\text { (Interval in cm) }\end{array}$ & $\begin{array}{c}(+) \text { 2V } \\
(0)\end{array}$ & $\begin{array}{c}\text { C:Ng } \\
(\mathrm{C}: \gamma) \\
(0)\end{array}$ & Type of Pyroxene \\
\hline $34-2,77-80$ & 50 & 36 & Augite \\
$34-3,86-89$ & 51 & 35 & Augite \\
$34-4,86-89$ & 58 & 40 & Augite \\
$35-1,87-90$ & 40 & 43 & Pigeonite-augite \\
$35-2,61-64$ & 50 & 41 & Augite \\
$36-2,15-17$ & 54 & 50 & Augite \\
$36-4,12-15$ & 20 & 37 & Pigeonite \\
$36-4,12-15$ & 56 & 58 & Augite \\
$36-5,34-36$ & 50 & 43 & Augite \\
$37-1,30-32$ & 60 & 58 & Augite \\
$37-2,70-72$ & 52 & 42 & Augite \\
$37-3,3-5$ & 60 & 58 & Augite \\
$37-3,73-75$ & 60 & 45 & Augite \\
& & & \\
\hline
\end{tabular}

$+20^{\circ}$ to $+68^{\circ}$, the angle $\mathrm{C}: \mathrm{Ng}(\gamma)$ from $25^{\circ}$ to $58^{\circ}$. These data indicate that pyroxene is present as pigeonite, augite, and titanium augite.

Pyroxene is subjected to strong secondary alterations. Often it is completely replaced by chlorite and hydromica aggregates. Sometimes pyroxene is replaced by pale green amphibole (uralite-actinolite) and aggregates of scaly talc and earthy leucoxene. There is calcitization of pyroxene.

Biotite with hydrobiotite developed over it is observed. Relics of primary biotite are rare, usually in the form of single reddish-brown plates. Hydrobiotite is common. Apatite (1\%-2\%), in the form of very fine regular prisms and needle crystals in plagioclase and pyroxene, is observed among accessories.

Besides the secondary minerals mentioned above, quartz and calcite form fine veins. Calcite also fills cavities and amygdules. The magmatic rocks are dis- 
sected the openings of fissures and slickensides with pyrite, chlorite, and calcite being developed over them.

The chemical composition is subjected to variations due both to crystaflization differentiation and metasomatosis (Table 3, Figures 3-8). The high potassium content does not appear to be completely related to secondary transformation (Figure 3 ), being governed by both the primary subalkaline composition of magmas and differentiation processes. The presence of the latter is well confirmed by Figures 4, 5, 6 and 9).

The average chemical composition of the "dry" magmatic rock (Table 4) differs from oceanic tholeiite by a higher alkalinity. The diabase and gabbro-diabase cored are probably the dike body filling a deep opening of dissection in the oceanic crust. The subalkaline composition of the magma is assumed to result from the deeper presence of the magmatic hearth as compared with tholeiitic magma.

\section{ICELANDIC PLATEAU}

One site (348) was drilled on the Icelandic Plateau, in the vicinity of its geometric center. Basalts were cored at a depth of 526.8 to 544 meters below marine terrigenous sediments. In the upper part of the basaltic body (Sample 33-1, 110-120 cm) olive-gray sandy siltstones with mica flakes and fine pyrite crystals were found. The absence of glassy surfaces of pillow lavas, the presence of sedimentary rock horizons, the variolitic fine crystalline basalt structure near the contact with the siltstones, the contact-metamorphism of the siltstones all suggest a cross-cutting nature of the basaltic body, as a sill.

Three principal basalt types are distinguished on the data of the megascopic and microscopic study hyalobasalts (variolitic basalts), basalts (dolerite basalts) and amygdaloidal basalts. Their petrologic description is found in site report chapter (this volume). See also Plate 5, Figures 1-4. Further study has made it possible to outline in detail their properties and distinguish one more type. These are olivine basalts (Sections 32-4, 33-1, 33-2, 34-1, 34-2) containing up to $5 \%$ of altered olivine replaced by iddingsite, calcite, and goethite. The microporphyritic and subophitic texture combined with the microdoleritic and tholeiitic is characteristic of the rock. The texture of the groundmass is intersertal, tholeiitic, microdoleritic.

Porphyritic phenocrysts as altered olivine, plagioclase, and rarely clinopyroxene are not common. Plagioclase (An 66-70) forms prisms and coarse $(1.0 \times$ $0.08 \mathrm{~mm}$ ) fresh polysynthetically twinned laths. Pyroxene constitutes compact aggregates with the typical wavy extinction. Underdeveloped plagioclase laths are common in pyroxene aggregates.

Secondary alterations of the basalts are slight. Glass is replaced by scuffy smectite aggregates, olivine is replaced by iddingsite-calcite-goethite aggregates. The basalts are dissected by thin veins of white calcite with pyrite and dark green chlorite. Coarse (to $1 \mathrm{~cm}$ ) calcite crystals are observed in bulges in the calcite veins.

The chemical composition of the basalts is uniform (Table 2). They are low-potassium tholeiites, similar to tholeiites of the Mid-Atlantic Ridge, differing from them by the higher iron content and the lower magnesium and aluminum content.

\section{JAN-MAYEN RIDGE}

Four sites $(346,347,349$, and 350 ) were drilled on the Jan-Mayen Ridge. In the northern part of the ridge, acoustic basement consists of compact terrigenous sedimentary rocks (sandstones, siltstones) probably of Eocene age. In the southern part of the ridge the basalt (tuff) breccia and basalts were drilled under late Eocene terrigenous sediments at Site 350. The thickness of the basalt (tuff) breccia is 17.7 meters (361.7-379.4 m below the sea floor) and for the basalts $(8.6 \mathrm{~m})$. The megascopic and microscopic description of breccia and basalts is given in Site Report Chapter 9 (this volume) See also Plate 5, Figure 5 and Plate 6, Figures 1-5. Additional mineralogical characteristics and the data on rock petrochemistry are presented here.

The breccia consists of unsorted, angular fragments of basalts, hyalobasalts, volcanic glass, and crystals of plagioclase and olivine. Coarse fragments are less altered than fine ones. The finest (microscopic) glass and olivine fragments are fully replaced by secondary minerals. The cementing microgranular and finegrained mass is also completely replaced by clay minerals of the smectite (montmorillonite-beidellite) type with $N=1.550$. Calcite developing over smectite sometimes completely replaces it. Often calcite replaces fragments as well forming fine edgings over their margins.

Microscopic investigation shows that there are about 95\% hyalobasalts and basalts among the breccia fragments, olivine, analcite basalts, and hyalobasalts being abundant. Olivine is completely replaced by secondary minerals, analcite is well preserved in the form of regular crystals.

The composition of basalts in the breccia fragments appears to be subalkaline. The chemical analysis shows a high potassium content in breccia (Table 1, Samples $350-14-2,86-89 \mathrm{~cm}$ and $16-1,74-77 \mathrm{~cm}$ ) confirm it. But these data cannot be used unconditionally as the rock has been subjected to strong secondary metasomatic alterations characterized by the supply of calcium and the loss of silica. It is likely, that there was a migration of sodium and potassium as well. The breccia is poorer in sodium and richer in potassium than the underlying basalts. The $\mathrm{Na}_{2} \mathrm{O} / \mathrm{K}_{2} \mathrm{O}$ ratio equals about 2 , which is different from oceanic tholeiites and characteristic of traps (Sheinman and Bajenova, 1972). There were two main varieties of basalts cored at Site 350: dolerite basalts and basalts. Varieties similar to olivine basalts and olivine dolerite basalts, with about $5 \%$ of olivine, are also present.

The texture of dolerite basalts is glomeroporphyritic. The texture of the groundmass is intersertal combined with the poikilophytic and tholeiitic. The structure is amygdaloidal. Plagioclase and pyroxene phenocrysts regularly impregnated amount to $20 \%$ $25 \%$. The largest plagioclase phenocryst is $3 \times 1 \mathrm{~mm}$. Plagioclase is fresh, polysynthetically twinned, sometimes zonal. Its composition ranges from An 58 to An 72. Pyroxene phenocrysts and microphenocrysts $(0.2-0.5 \mathrm{~mm})$ consist of short-prismatic grains with different degrees of idiomorphism. They are often observed near accumulations of plagioclase laths forming indistinct taxitic areas of a more coarse-grained 
constitution. Clinopyroxene is present in the shape of relatively fresh prisms with $\mathrm{C}: \mathrm{Ng}(\gamma)=40^{\circ}-45^{\circ},+2 \mathrm{~V}=$ $50^{\circ}-60^{\circ}$ (augite). There are also isometrical pyroxene prisms with $\mathrm{C}: \mathrm{Ng}(\gamma)=5^{\circ}-10^{\circ},+2 \mathrm{~V}=70^{\circ}-85^{\circ}$, dispersion $r<v$, (closer to orthopyroxene). However, most of the orthopyroxene appears to be replaced by a chloritesmectite mass. Rounded amygdules consisting of smectite in the margins and sheaf-like zeolite crystals in the center are present. There are areas of brown glass (5\%$7 \%$ ), and for the most part the glass is replaced by brownish-green smectite aggregates. However, on the whole, the secondary alteration of the Site 350 basalts is slight, and in comparison with other sites, it is the least. Openings of the fissures and slickensides with calcite and chlorite over walls are rare.

On the basis of three samples $(16-1,114-117 \mathrm{~cm}, 16-2$, $134-137 \mathrm{~cm}, 16-3,101-103 \mathrm{~cm})$, the chemical composition of basalts is uniform. They are low-aluminum, high-titanium basalts with a higher content of potassium. The average chemical composition of the "dry" rock is similar to Tertiary traps of Iceland, the Faeroe Islands, and the Icelandic-Faeroe Ridge (Table 4, Figure 9).

\section{SUMMARY AND DISCUSSION}

Nine of 16 sites drilled in the Norway and Greenland seas reached acoustic basement consisting of magmatic rocks. The study of the latter shows that they are outpourings of subvolcanic and hypabyssal facies. Only in two cases (Sites 337 and 345) can one suggest submarine lava flows. Breccia horizons with glass, hyalobasalts, amygdaloidal, and vesicular basalts developed in the roof of lava streams are present here. Hypabyssal diabases and gabbro-diabases were drilled at Site 344 . At the other six sites, both thick lava streams and sills, and small dikes consist of basalts. At two sites ( 345 and 350 ) a basaltic breccia was recovered. It may represent both a lava breccia (Site 345 ), and an eruptive breccia (Site 348) filling the volcanic channel. At one Site (336) a red chemical weathering crust developed over the volcanics. At Site 338, only relics of eluvium developed over basalts were preserved.

The degree of secondary mineral alterations is different. The basaltic breccia is strongly altered. Its cement and small fragments are completely replaced by chlorite, smectite, calcite, and other minerals. Based on the degree of secondary alteration, the basalts are divided into altered and little-altered types. Basalts at Sites 348 and 350 are little altered, with occasional fresh glass preserved in their groundmass. In basalts at other sites, glass is completely replaced by smectite and chlorite; olivine is completely replaced as well; pyroxene and plagioclase are partly altered. Judging by the composition of secondary minerals, it is concluded that rocks of acoustic basement are in an early stage of metamorphism, and the intensity of their transformation depends on the age, primary composition, structural and textural features of the rock, and on the structural type of the earth's crust. Postvolcanic hydrothermal processes and associated carbonatization, chloritization, and pyritization are also observed.
Based on petrochemical characteristics, the volcanic rocks are divided into two main types: (1) basalts similar to low-alkaline tholeiites (Sites 336, 338, 348), and (2) alkaline and subalkaline basalts (Sites 337, 342, $343,350)$. Acid and intermediate rocks are not present. High-aluminum alkaline basalts are present at one site (345). Variations of the chemical composition of the volcanics in different regions also differ. Basalts from the V $\phi$ ring Plateau, with tholeiitic and alkaline rock types, have the most significant variations. Slight variations in basalt composition are observed at sites on the Jan-Mayen Ridge (Site 350) and the Icelandic Plateau (Site 348).

Comparing the average chemical composition of basalts cored from sites on DSDP Leg 38 with that of basalts in other ocean areas and on land (Table 4, Figures 10, 11), it will be noted that the basalts are (1) closer to Paleogene-Neogene plateau basalts of east Iceland and the Faeroe Islands (Sites 337, 342, 350); (2) closer to tholeiites of the Mid-Atlantic Ridge (Sites 336, 338,348 ), differing from them by low magnesia content and high iron content; and (3) similar to alkaline basalts developed in transform fracture zones (Sites $343,344,345)$. However, in all cases, basalts of any region have specific properties typical for that region.

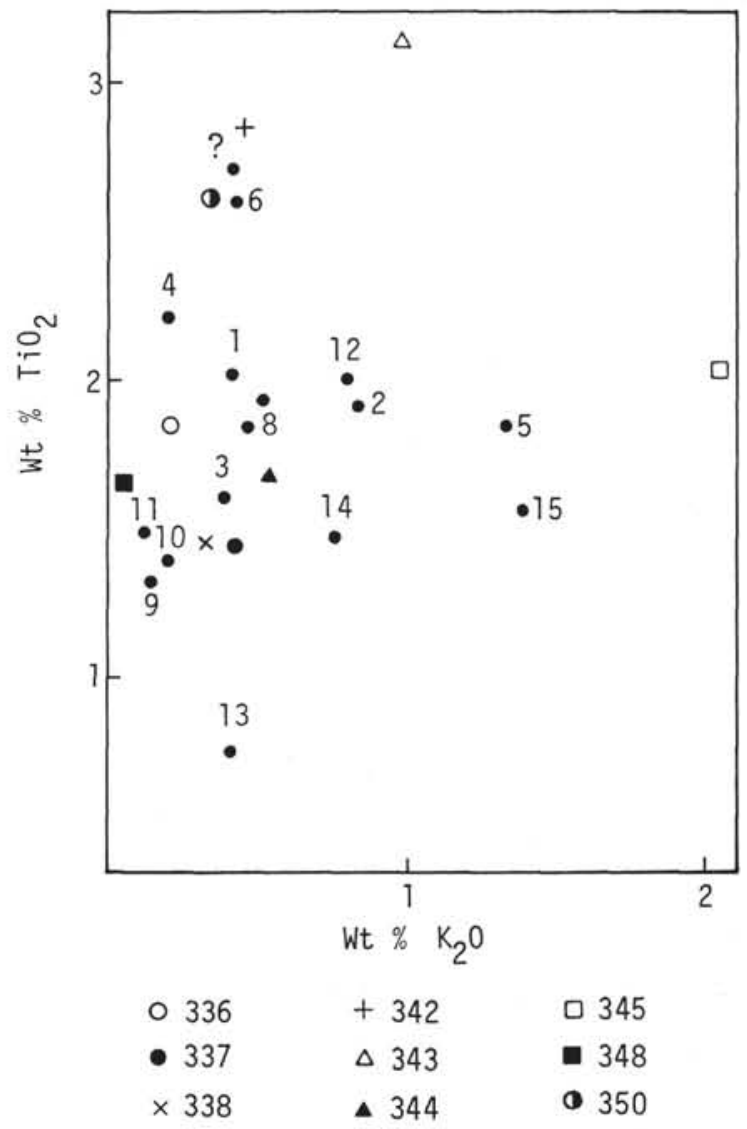

Figure 10. Distribution of magmatic rocks of Leg 38 and different types of oceanic and continental basalts into coordinates of $\mathrm{TiO}_{2}-\mathrm{K}_{2} \mathrm{O}$. Average composition and number according to Table 4. 


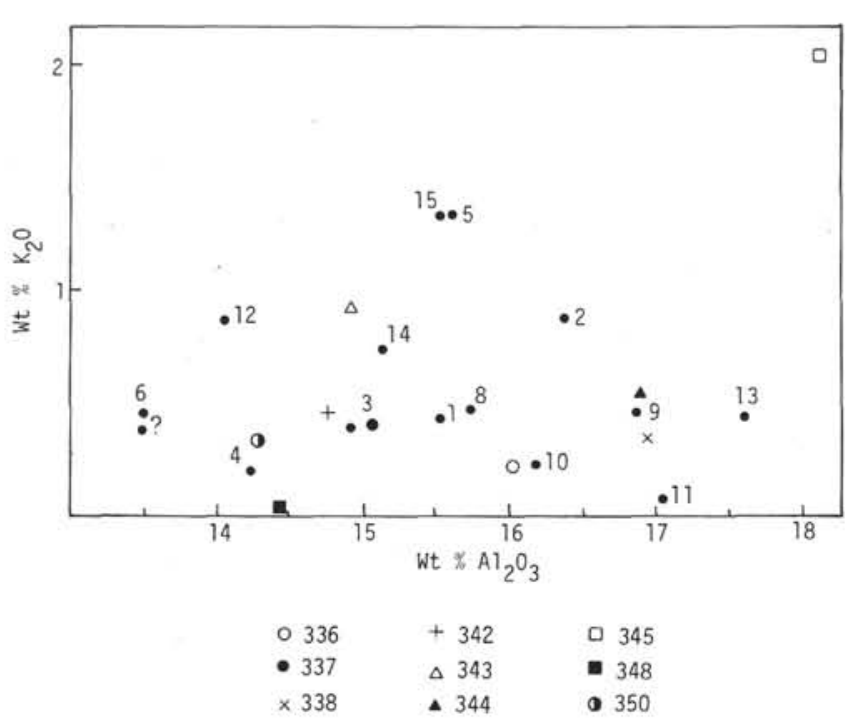

Figure 11. Distribution of magmatic rocks of Leg 38 and different types of oceanic and continental basalts into coordinates of $\mathrm{K}_{2} \mathrm{O}-\mathrm{Al}_{2} \mathrm{O}_{3}$.

This suggests heterogeneity of the earth's crustal structure and of the composition of the mantle from which the magma was derived.

\section{REFERENCES}

Aumento, F., 1968. The Mid-Atlantic Ridge near $45^{\circ} \mathrm{N}$ : Basalts from the area of Confederation Peak: Canadian J. Earth Sci., v. 5, p. 1-21.
Baskina, V.A., 1971. The magmatic activity of Iceland: Soviet Geol., p. 94-108.

Dmitriev, L.V., 1974. Petrochemical study of basaltic basement of the Mid-Indian ridge. Leg. 24, Initial Reports, v. XXIV, p. 767-779.

Engel, A.E., Engel, C.G., and Havens, R.G., 1965. Chemical characteristics of oceanic basalts and the upper mantle: Geol. Soc. Am. Bull., v. 76, p. 719-734.

Kharin, G.S., in press. The magmatic rocks of the IcelandFaeroe Ridge: Moscow Oceanol.

Kharin, G.S. and Bogdanov, U.A., 1974. Basalt of deep-sea Romanche Trench: Moscow Oceanol., v. 14, p. 677-681.

Kuno, H., 1960. High-alumina basalt: J. Petrol., v. 1, p. 121145.

Kutolin, V.A., 1972. Problems of basaltic petrochemistry and petrology: Novosibirsk (Nauka), p. 207.

Lisitzina, N.A., 1973. Removal of chemical elements at the weathering of basic rocks: Moscow (Nauka), p. 228.

Noe-Nygaard, A., 1966. Chemical composition of tholeiitic basalts from the Wyville-Thompson ridge belt: Nature, v. 212 , p. $60-62$.

Sheinman, Y.M. and Bajenova, G.H., 1972. General geological value of some basalt content features in ocean and continents: Moscow Soc. Naturalists Geol. Bull., p. 81-101.

Schilling, J.G., 1973. Iceland mantle plume: geochemical study of Reykjanes Ridge: Nature, v. 242, p. 565-571.

Thompson, R.N., Esson, J., and Dunham, A.C., 1972. Major element chemical variation in Eocene lavas of the Isle of Skye, Scotland: J. Petrol., v. 13, p. 219-254.

Vogt, R.R., Ostenso, N.A., and Johnson, G.L., 1970. Magnetic and bathymetric data bearing on sea-floor spreading North of Iceland: J. Geophys. Res., v. 75, p. 903-920. 


\section{PLATE 1}

Figure 1 Fine-grained porphyric basalt with microintersertal groundmass. To the right are resorpizated intratelluric phenocrysts of plagioclase: Sample 33641-1 (without analyzer).

Figure 2 Amygdaloidal chloritized basalt. The zonal amygdules are filled with smectite, chlorite, and calcite: Sample 336-44-2, 60-63 cm (without analyzer).

Figure 3 Variolitic hyalobasalt. The olivine and augite phenocrysts are in a dark glassy variolitic groundmass: Sample 337-13-1, 80-83 cm (without analyzer).

Figure 4 Amygdaloidal variolitic hyalobasalt. The amygdules (at the bottom, right) are filled by smectite and calcite: Sample 337-14-2, 91-94 cm (without analyzer).

Figure 5 Amygdules and vesicles in variolitic hyalobasalt. The vesicle in center is filled with smectite: Sample $337-15-2,41-44 \mathrm{~cm}$ (without analyzer).

Figure 6 Variolitic olivine basalt. Idiomorphic olivine crystals have been the centers of variole construction: Sample 337-13-1, $84-87 \mathrm{~cm}$ (without analyzer). 
PLATE 1

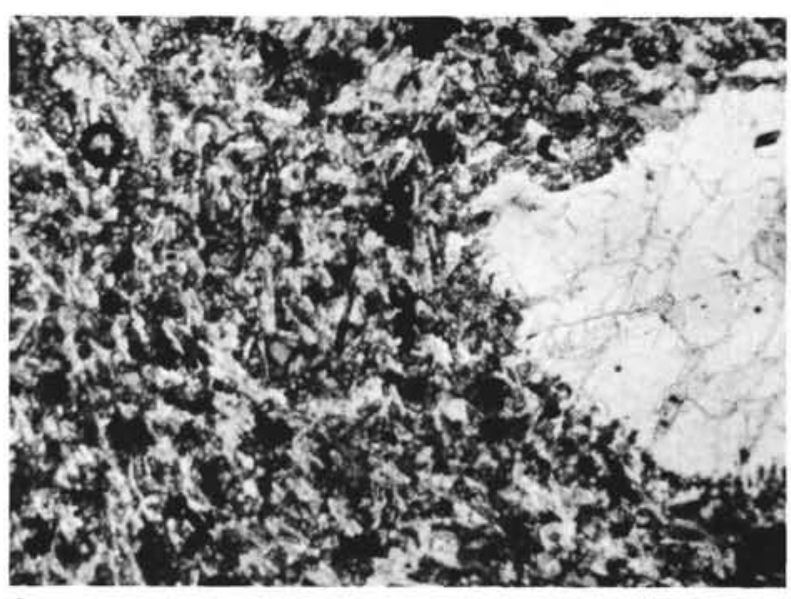

1

$0.5 \mathrm{~mm}$
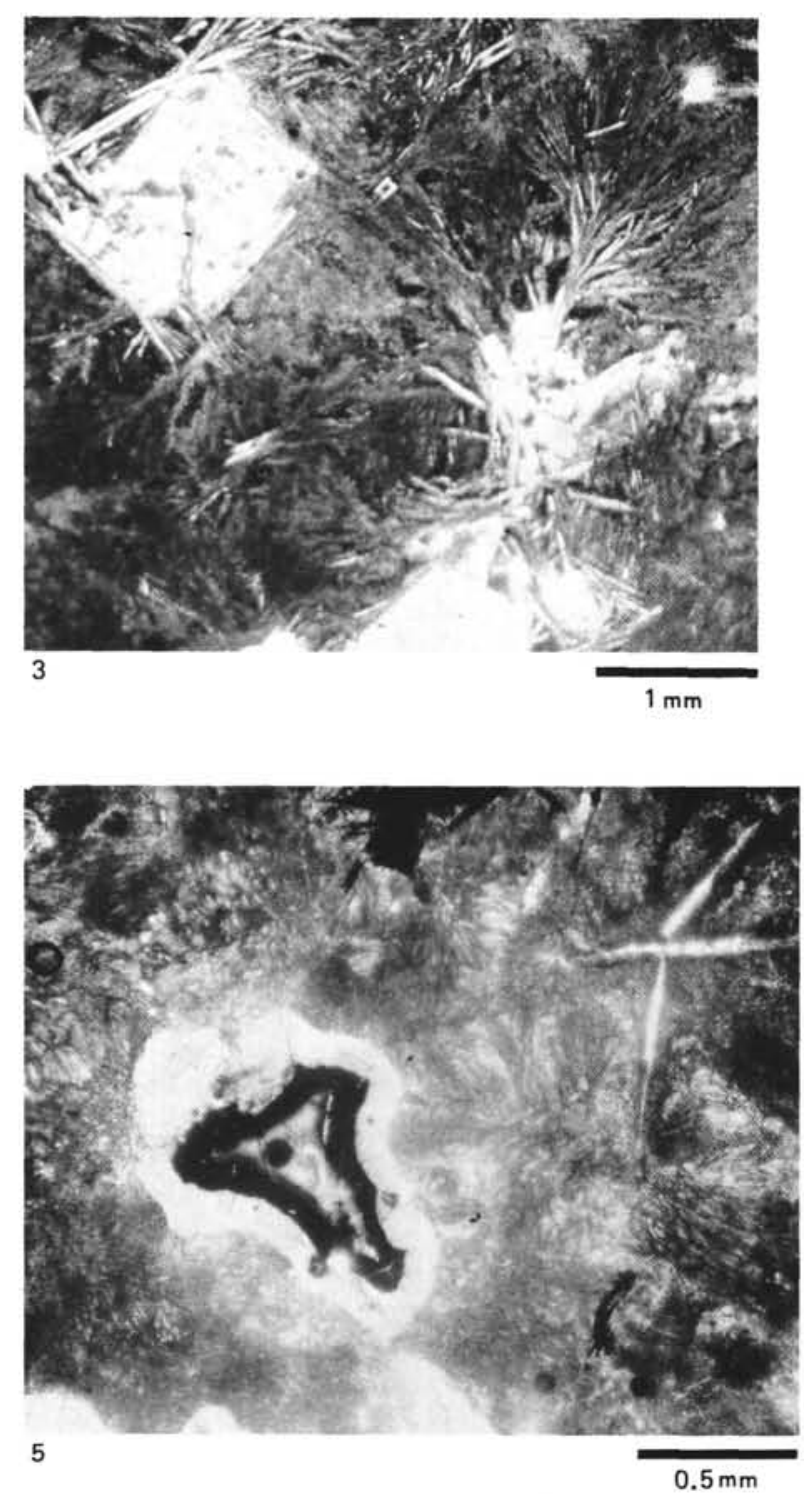
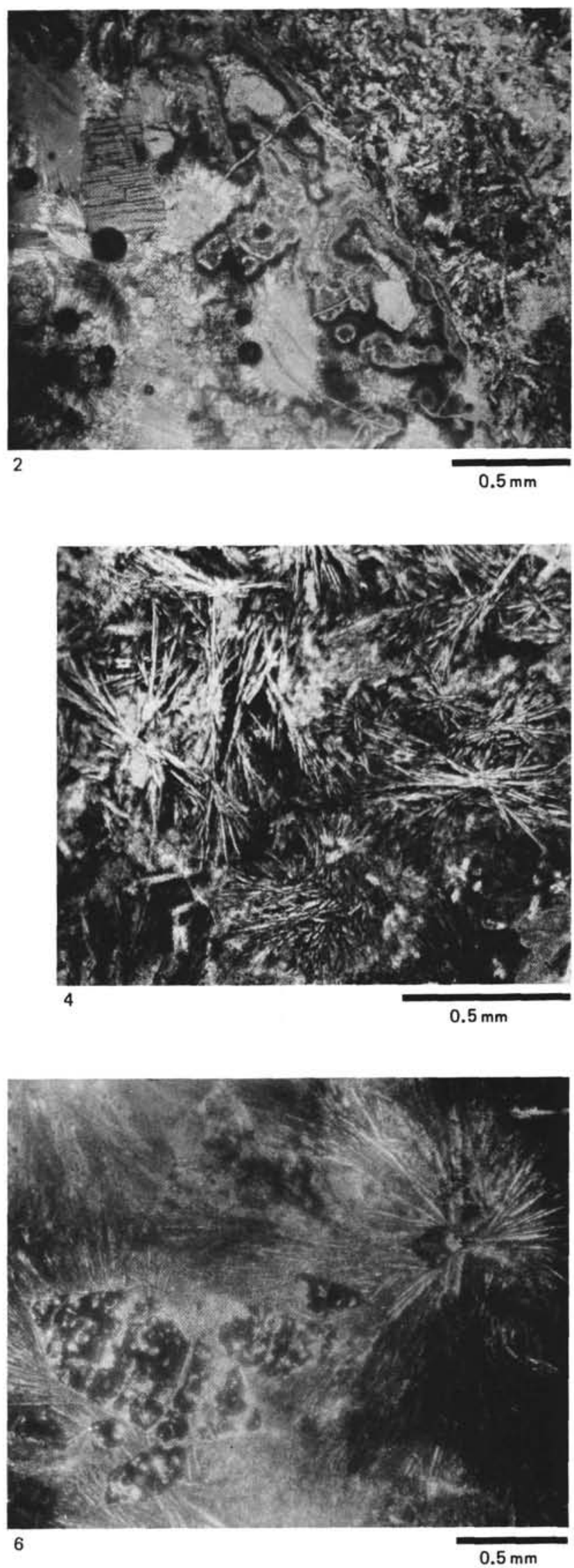


\section{PLATE 2}

Figure 1 Coarse phyric plagioclasic basalt with microintersertal texture of groundmass and intratelluric plagioclase phenocrysts (gray): Sample 338-43-3, $108-111 \mathrm{~cm}$ (without analyzer).

Figure 2 Olivine basalt. Aggregations of fine crystals of altered olivine between fine plagioclase laths: Sample $338-42-2,144-147 \mathrm{~cm}$ (without analyzer).

Figure 3 Coarse phyric plagioclasic basalt (dolerite-basalt) with intersertal texture of groundmass. Resorbed crystals of plagioclase with inclusions of relict glass (dark) in cleavage fissures: Sample 342-8-4, $127-130 \mathrm{~cm}$ (without analyzer).

Figure 4 Phyric basalt with olivine which is replaced by iddingsite (black, in center), and plagioclase (gray, to the right): Sample $342-8-4,19-22 \mathrm{~cm}$ (without analyzer).

Figure $5 \quad$ Amygdaloidal hyalobasalt with variolitic-vitreous texture of groundmass: The amygdules are filled with chlorite and smectite: Sample 343-12-2, 140$143 \mathrm{~cm}$ (without analyzer).

Figure 6 Amygdaloidal basalt with intersertal texture of groundmass: Sample 343-13-2, 5-8 cm (without analyzer). 


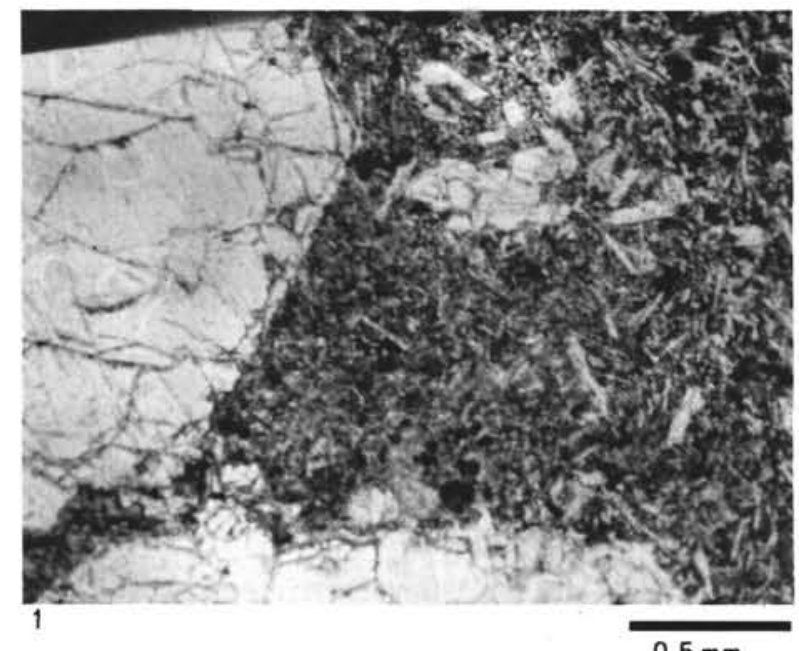

$0.5 \mathrm{~mm}$
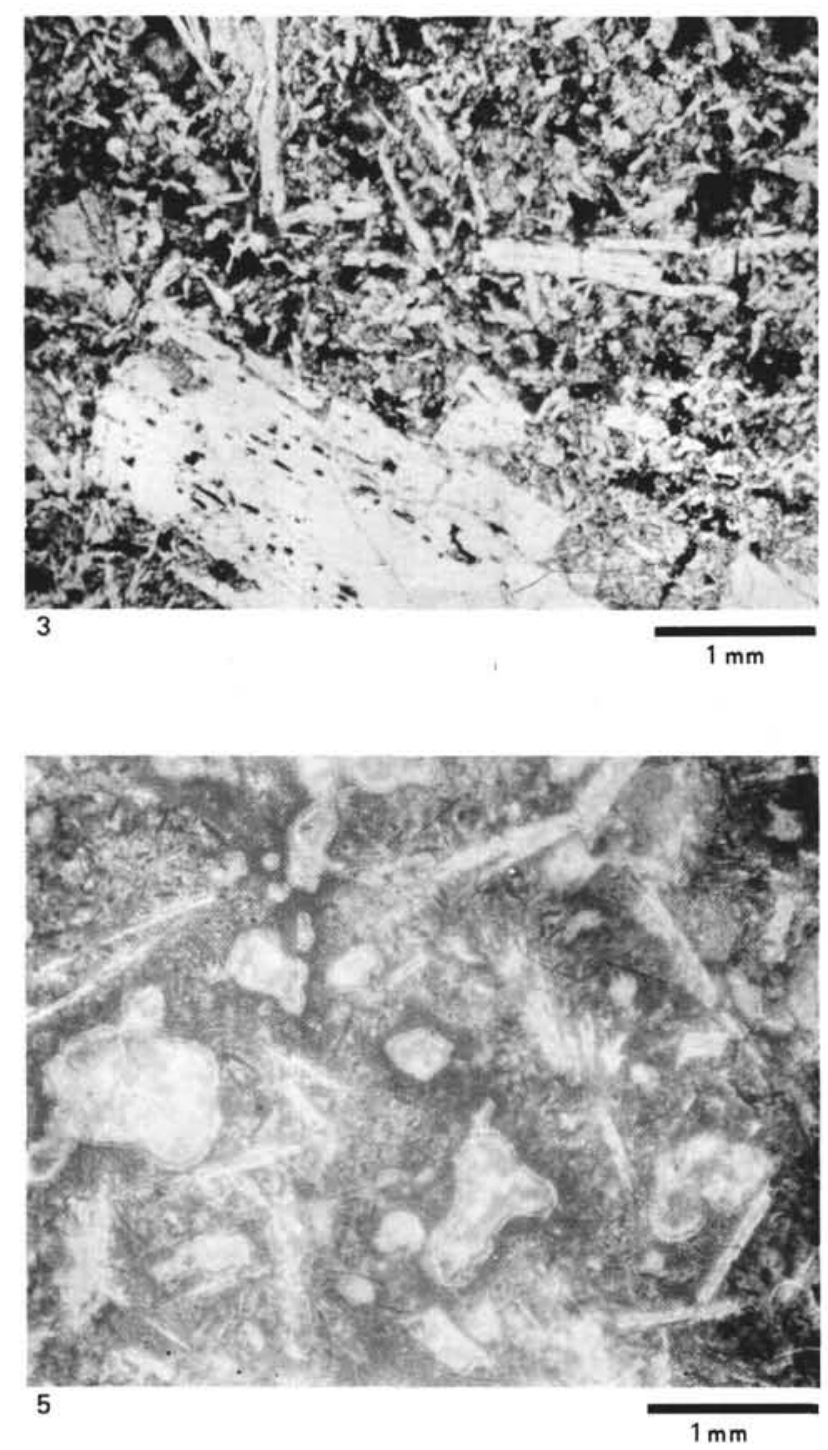
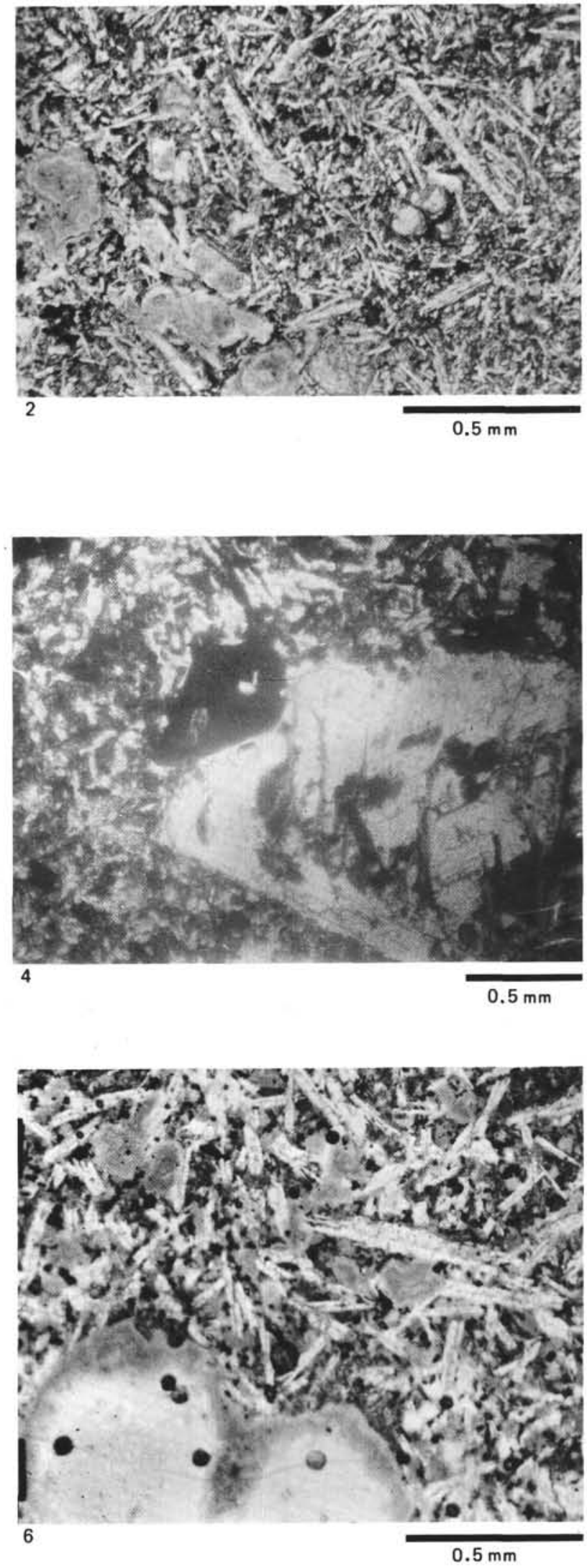
PLATE 3

Figure 1 Medium-grained dolerite. Poikilophitic texture, taxitic structure: Sample 344-34, 114-117 cm (without analyzer).

Figure 2 Medium-grained dolerite. Ophitic texture, the laths of plagioclase predominate. Pyrite crystals (black): Sample 344-34-2, 127-130 cm (without analyzer).

Figure 3 Gabbro-diabasic texture in dolerite (diabase). Leucocratic plot of a rock; rare pyroxene crystals (dark) between idiomorphic plagioclase crystals: Sample 344-35-2, 61-64 cm (without analyzer).

Figure 4 The same as Figure 3, but with analyzer.

Figure 5 Gabbroic texture in fine-grained gabbro. The plagioclase crystals (gray) have the same idiomorphic degree with pyroxene crystals (dark): Sample 344-36-3, 135-137 cm (without analyzer).

Figure 6 Coarse-grained dolerite with poikilophytic textures. The plagioclase twins poikilitic intergrown in the coarse augite crystal: Sample 344-35-4, 36$39 \mathrm{~cm}$ (with analyzer). 

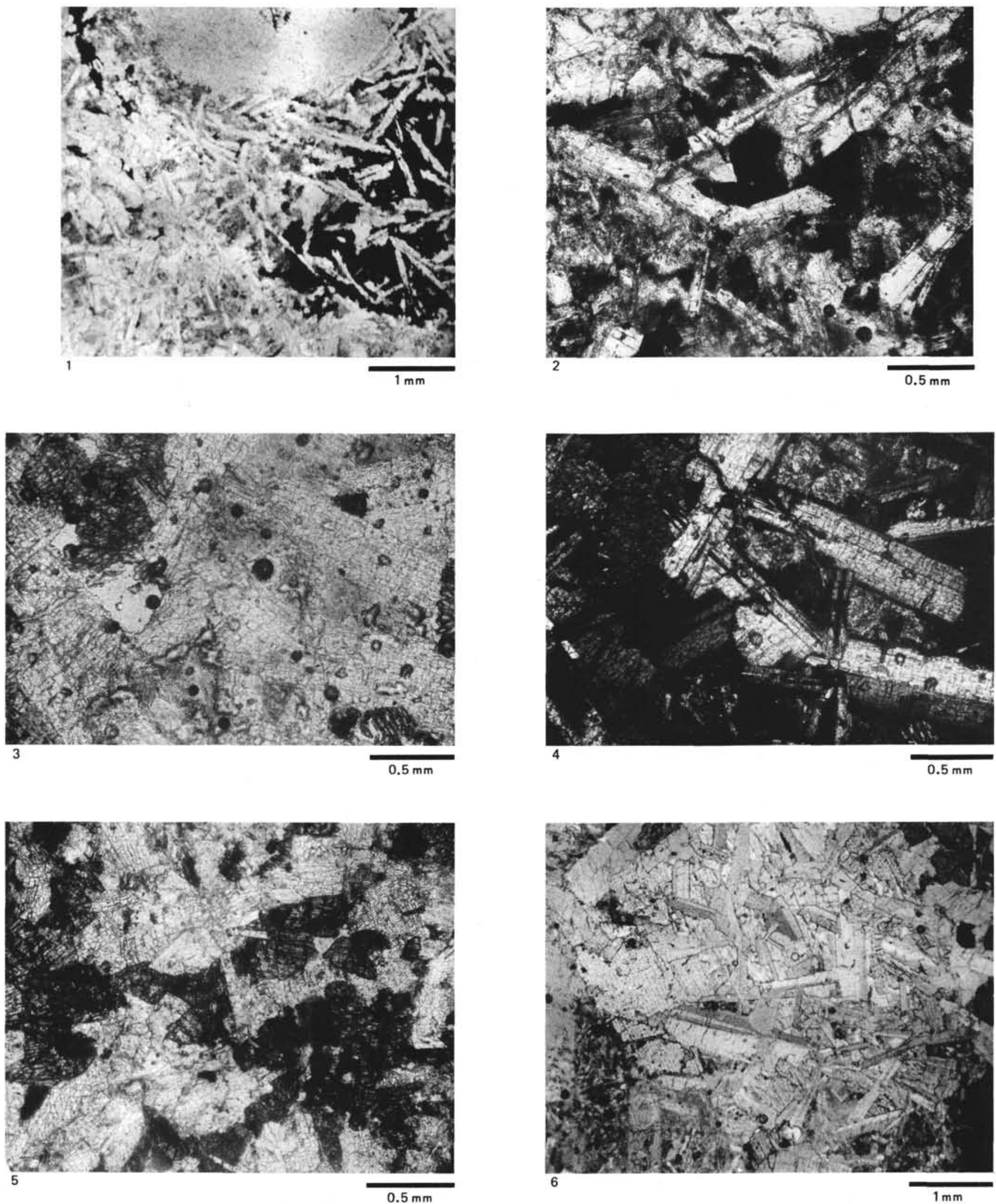


\section{PLATE 4}

Figure 1 Medium-grained gabbro-dolerite with gabbroic texture. Plagioclase crystals (gray)-more idiomorphic than clinopyroxene crystals (dark gray): Sample 344-37-3, 73-75 cm (without analyzer).

Figure 2 The same as Figure 1, but with analyzer.

Figure 3 Basalt breccia. Fragments of olivine basalt (to the right) are cemented by smectite matrix with typical stripy-concentric structure. Joint is filled by calcite and smectite: Sample 345-34-1, 87-90 cm (without analyzer).

Figure 4 Taxitic amygdaloidal hyalobasalt. Stripped disposition of glassy (dark) and crystal (gray): Sample $345-35$, CC (without analyzer).

Figure $5 \quad$ Basalt breccia. Fragment of olivine hyalobasalt (dark) and smectite-calcite matrix with radialconcentric structure: Sample 345-33-1, 126-129 cm (without analyzer).

Figure 6 Amygdaloidal hyalobasalt. Poor zone of magma chilling around the amygdules which are filled with smectite: Sample 345-35-2, 128-131 cm (without analyzer). 
PLATE 4
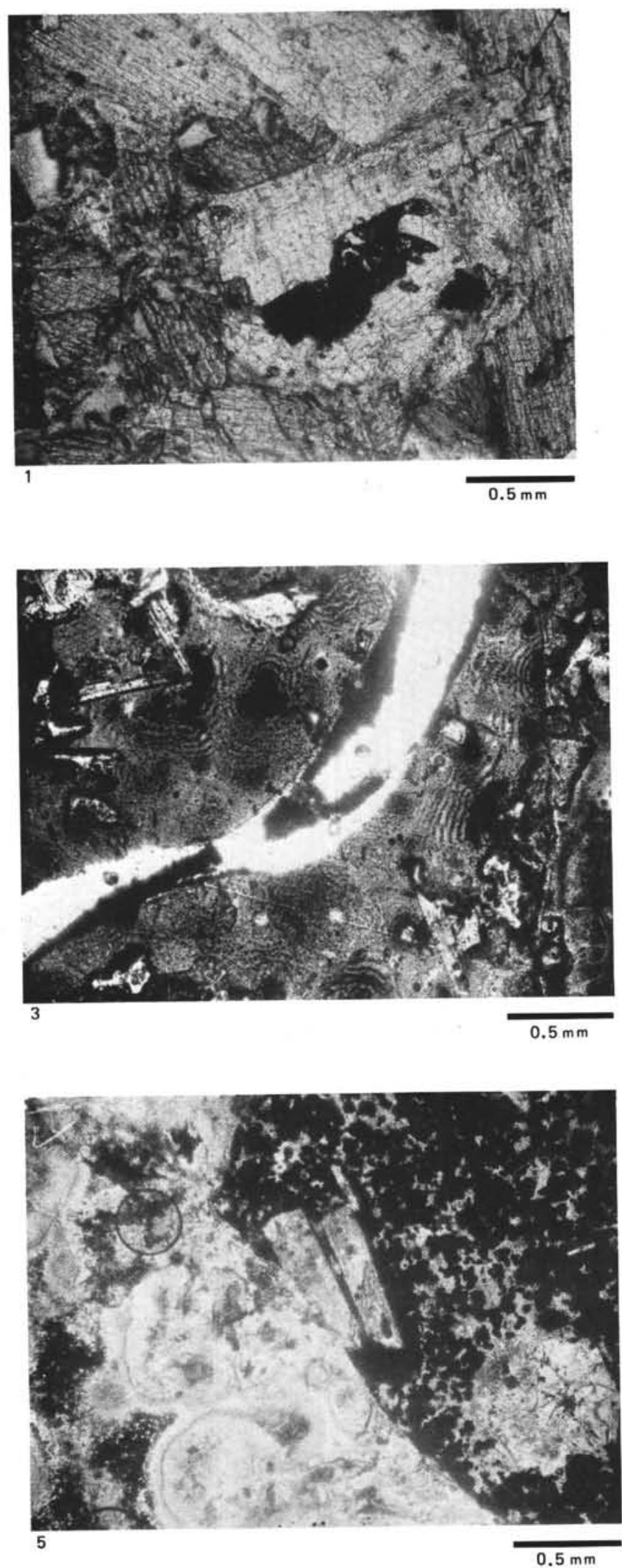
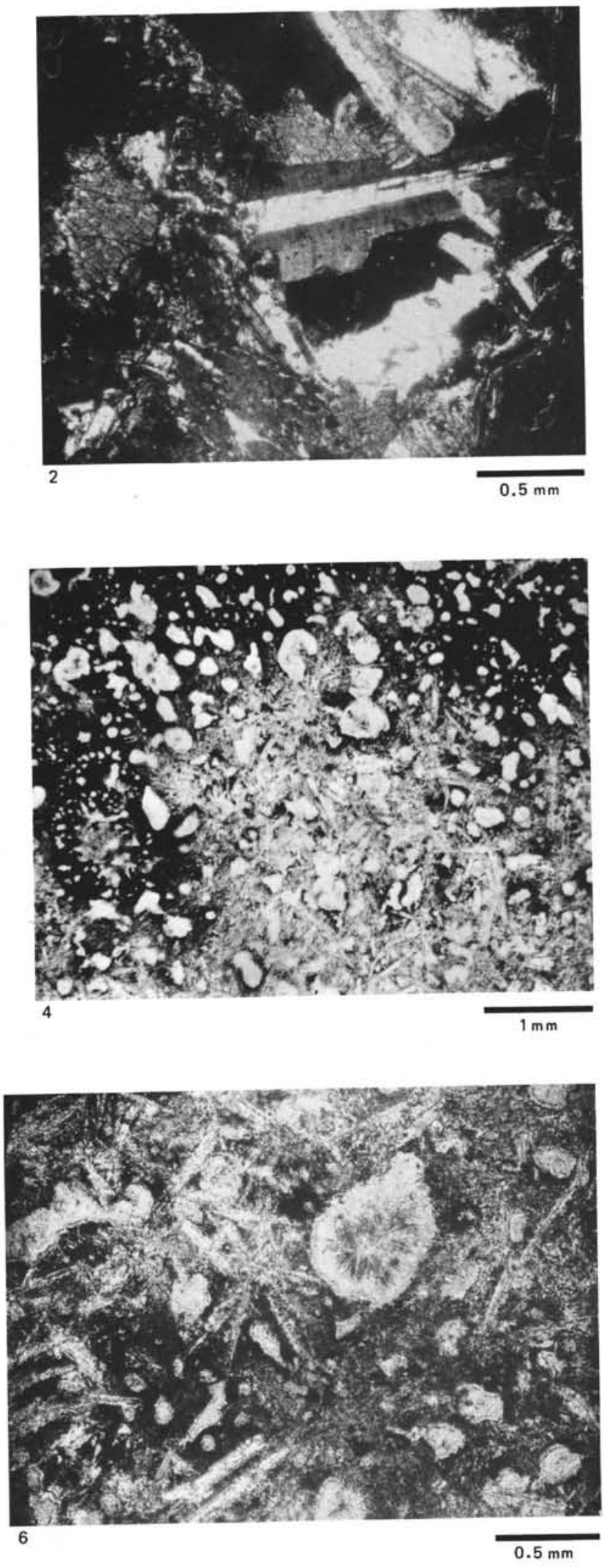


\section{PLATE 5}

Figure 1 Variolitic texture of hyalobasalt in embryo. Rare amygdules are filled with smectite. Skeletal laths of plagioclase: Sample 348-33-1, 126-129 cm (without analyzer).

Figure 2 Medium-grained basalt (dolerite-basalt) near to microdolerite with dolerite texture: Sample 34834-2, 146-149 (without analyzer).

Figure 3 Basalt with trachydolerite texture conditioned by subparallel disposition of skeletal plagioclase laths. Fine pyroxene aggregates and glassy groundmass: Sample 348-32-4, $43-46 \mathrm{~cm}$ (without analyzer).

Figure 4 Amygdaloidal basalt with ophitic texture. Poor skeletal plagioclase with split ends. Amygdule is filled by smectite and calcite: Sample 348-34-2, $104-108 \mathrm{~cm}$ (without analyzer).

Figure 5 Siltstone from interbed between basalt tuff breccia. Branching veins of calcite (white) cut the rock: Sample 350-14-2, 108-110 cm (without analyzer). 


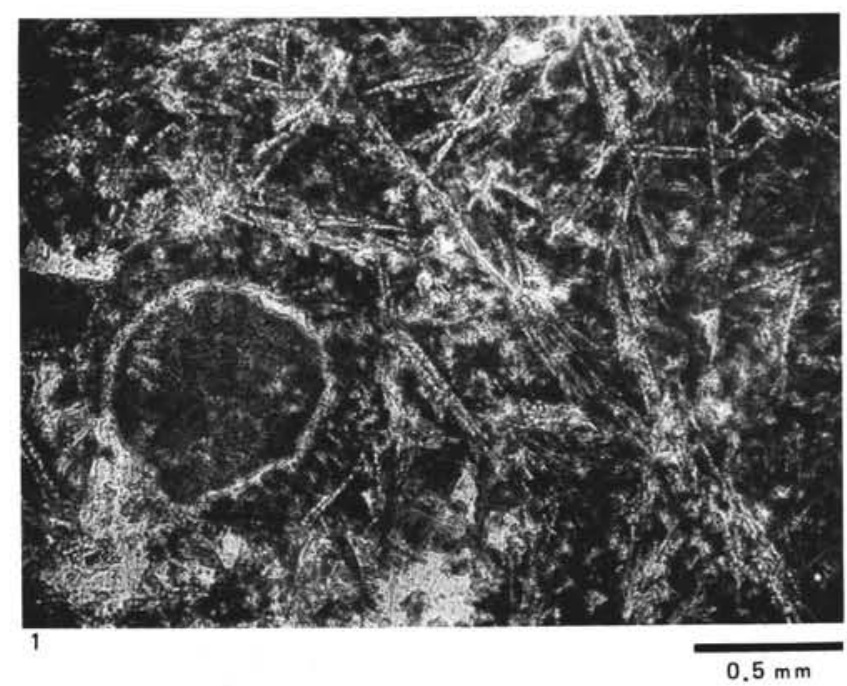

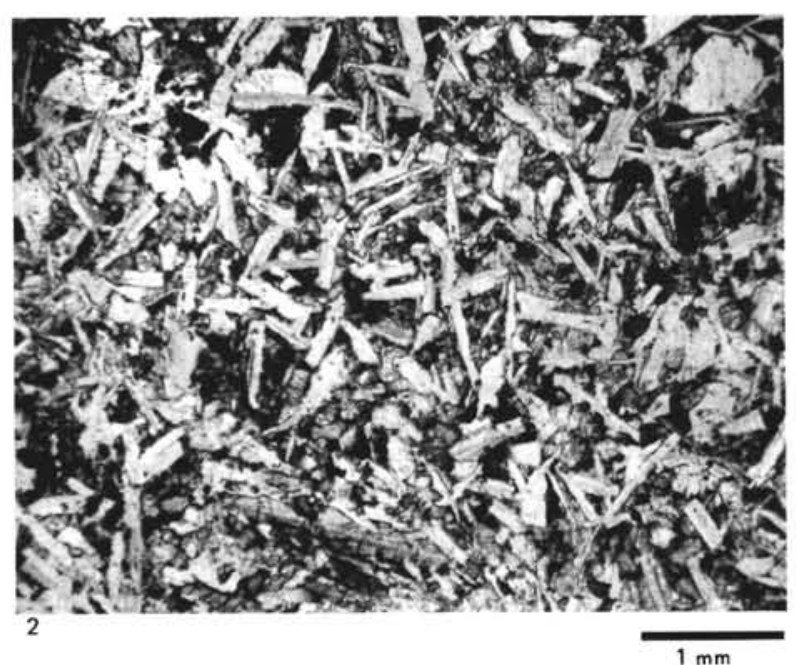

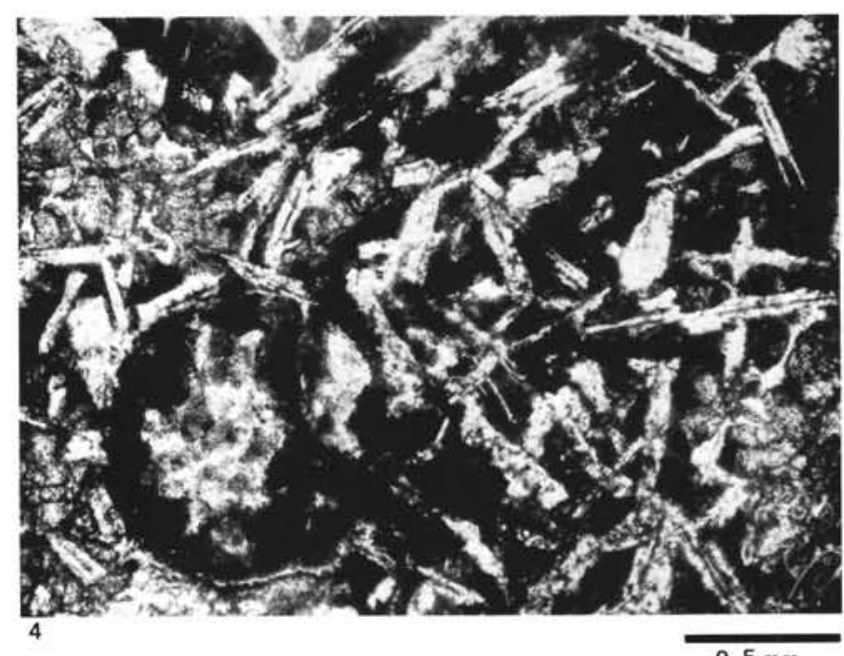

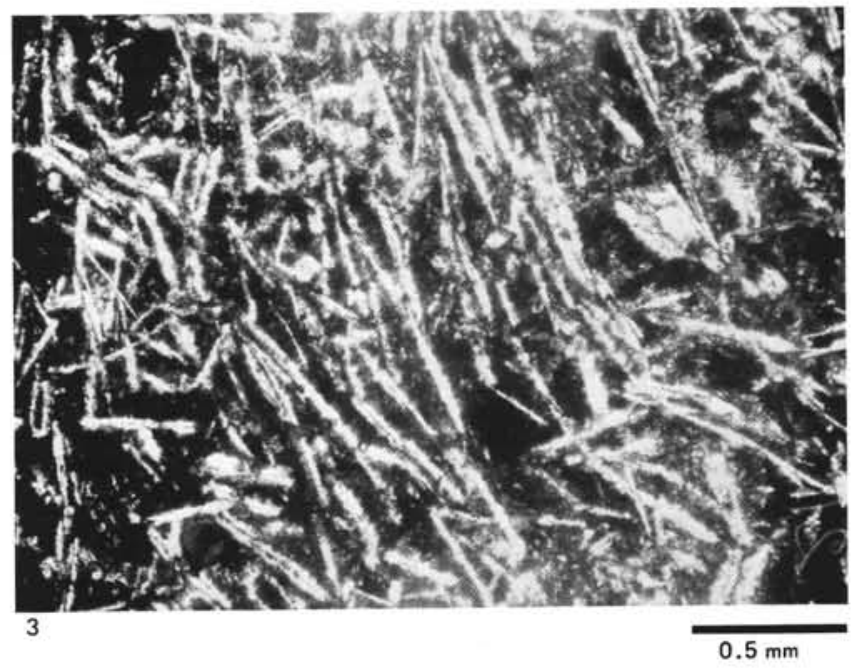

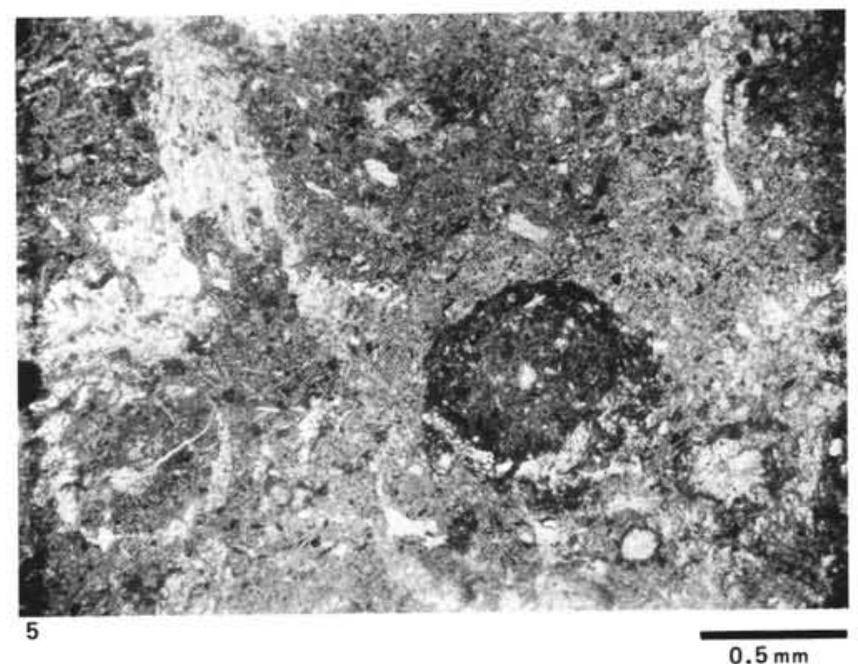




\section{PLATE 6}

Figure $1 \quad$ Basalt breccia. Fragment of hyalobasalt (black) with plagioclase laths. Radial concentric calcite matrix (gray): Sample 350-14-3, 18-21 cm (without analyzer).

Figure 2 Breccia. Fragments of olivine basalt with analcite cemented by smectite-calcite-hydrogoethite matrix (black) is cut by smectite veins (gray): Sample 350$14-3,135-138 \mathrm{~cm}$ (without analyzer).

Figure 3 Basalt with trachydolerite texture. Fine "table" plagioclase crystals disposed subparallel: Sample $350-16-1,112-114 \mathrm{~cm}$ (without analyzer).

Figure 4 Fine-grained phyric dolerite-basalt. Between plagioclase laths the remainder of glassy groundmass and clinopyroxene aggregate: Sample 35016-3, 114-117 cm (without analyzer).

Figure $5 \quad$ Basalt with tholeiitic texture. Between laths of plagioclase-clinopyroxene grains and glassy remains: Sample 350-16-2, 115-118 cm (without analyzer). 
PLATE 6

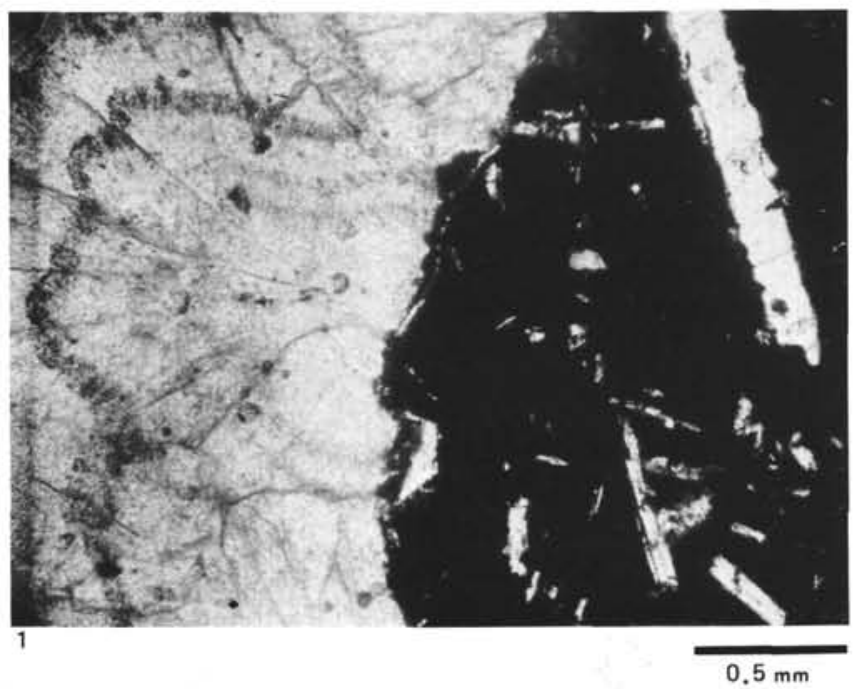

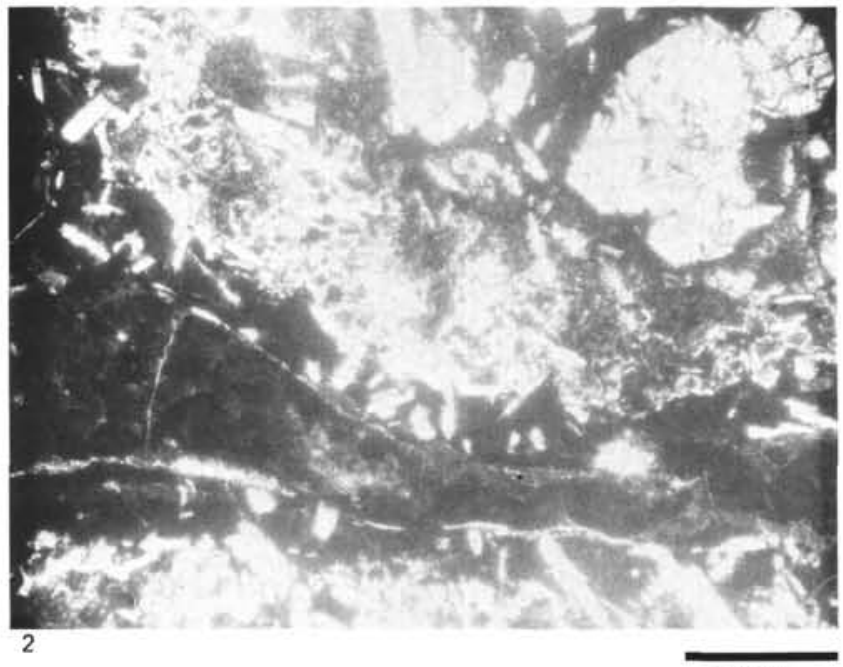

$0.5 \mathrm{~mm}$

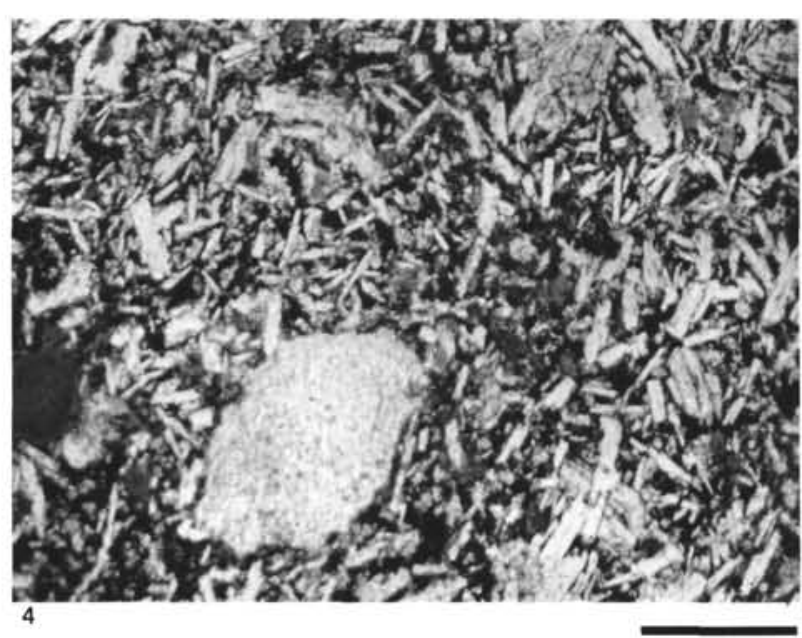

$1 \mathrm{~mm}$
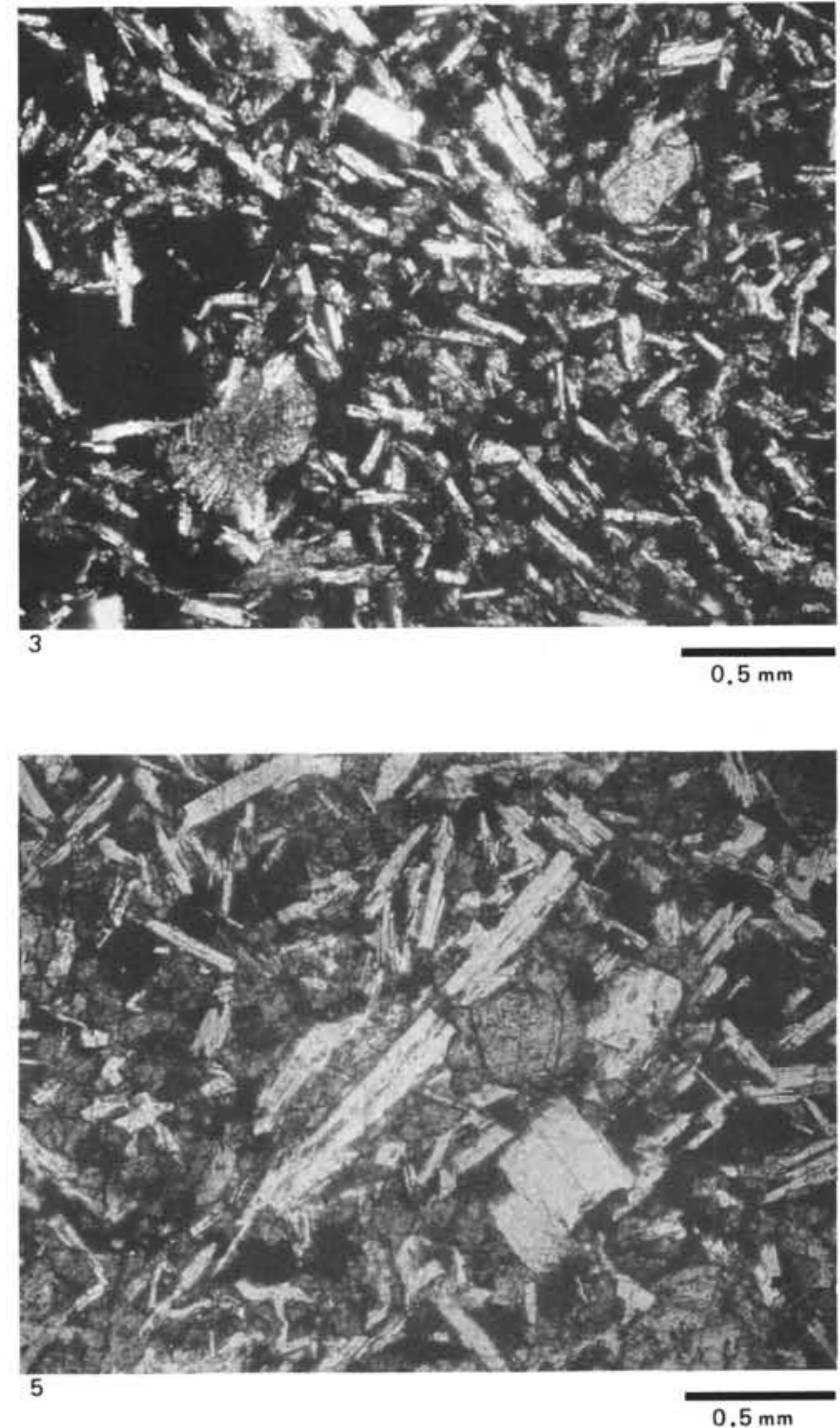